\title{
The tectono-metamorphic evolution of a dismembered ophiolite (Tinos, Cyclades, Greece)
}

\author{
YARON KATZIR*, ALAN MATTHEWS*, ZVI GARFUNKEL*, MANFRED SCHLIESTEDT $\dagger$ \\ \& DOV AVIGAD*
}

\author{
* Institute of Earth Sciences, The Hebrew University of Jerusalem, Jerusalem 91904, Israel \\ $\dagger$ Institut für Mineralogie, Universität Hannover, Welfengarten 1, D-30167, Hannover, Germany
}

(Received 8 June 1995; accepted 5 March 1996)

\begin{abstract}
The six exposures of the Upper tectonic Unit of the Cycladic Massif occurring on the island of Tinos are shown to comprise a metamorphosed dismembered ophiolite complex. The common stratigraphic section consisting of tens-of-metres- thick tectonic slices of mafic phyllites overlain by serpentinites and gabbros is considered to have been derived by a combination of thrusting during obduction and subsequent attenuation by low-angle normal faults. All rock types show evidence of a phase of regional greenschistfacies metamorphism, which in the case of the phyllites is accompanied by penetrative deformation. The greenschist-facies metamorphism in gabbros is preceded by high temperature sea-floor amphibolite-facies alteration, whereas in the serpentinites, the antigorite + forsterite greenschist-facies assemblage overprinted an earlier low temperature lizardite serpentinite. Trace element patterns of the mafic phyllites and a harzburgitic origin of meta-serpentinites suggest a supra subduction zone (SSZ) affinity for the ophiolitic suite. $\delta^{18} \mathrm{O}$ values of phyllites, gabbros and serpentinites range from 6 to $15 \%$. Model calculations indicate that such values are consistent with low temperature $\left(50-200^{\circ} \mathrm{C}\right)$ alteration of parent rocks by sea-water at varying water/rock ratios. This would agree with the early low temperature mineralogy of the serpentinites, but the early high temperature alteration of the gabbros would require the presence of ${ }^{18} \mathrm{O}$-enriched sea-water.

The following overall history is suggested for Tinos ophiolitic slices. (1) Oceanic crust was generated at a supra-subduction zone spreading centre with high temperature alteration of gabbros. (2) Tectonic disturbance (its early hot stages recorded in an amphibolitic shear zone at the base of serpentinites) brought the already cooled ultramafics into direct contact with sea-water and caused low- $T$ serpentinization. (3) Tectonism after cooling involved thrusting which caused repetition and inversion of the original order of the oceanic suite. (4) Regional metamorphism of all the ophiolite components at greenschist-facies conditions $\left(\sim 450^{\circ} \mathrm{C}\right)$ overprinted the early alteration mineralogy. It was probably induced by continued thrusting and piling up of nappes. The Tinos ophiolite, dated as late Cretaceous and genetically related to other low pressure rock-units of the same age in the Aegean, differs in age and degree of dismemberment and metamorphism from ophiolites in mainland Greece.
\end{abstract}

\section{Introduction}

Ophiolites, interpreted as fragments of oceanic lithosphere emplaced onto continental margins, are typically exposed along orogenic belts where they are considered to record the presence of ancient zones of plate convergence. The western ophiolitic belt of the Alpine orogen in the Hellenides (Fig. 1) consists of rock-sequences that, despite a moderate degree of disruption, may be considered to be good examples of fully developed ophiolite suites. These unmetamorphosed ophiolite complexes (e.g. Vourinos, northern Greece: Moores, 1969; Othris, east central Greece: Smith et al. 1975) are interpreted as having originated in a Mesozoic Neo-Tethyan oceanic basin, the Pindos Ocean (Biju-Duval, Dercourt \& Le Pichon, 1977; Robertson et al. 1991). Studies of the timing of their emplacement show that they were thrust onto Mesozoic carbonate platform sequences in the late Jurassic and then covered by early Cretaceous transgressive limestones (Aubouin et al. 1970; Smith, Woodcock \& Naylor, 1979). The Pindos Ocean did not completely close during the late Jurassic ophiolite emplacement (termed the Eo-Hellenic event) and survived as a small ocean basin until its final closure in early Tertiary time (Jones \& Robertson, 1991).

In the Cycladic Massif of the Aegean Sea, a southeastern segment of the Hellenides, metamorphosed ophiolitic rock associations occur within or overlying Eocene high pressure metamorphic rock sequences ('Lower Unit', = 'Blueschist Unit'; Fig. 1). Bonneau (1984) and Papanikolaou (1987) attribute the high pressure metamorphic event to the closure of the Mesozoic Pindos basin by subduction and eventual collision of the Apulian with the Pelagonian microplates. Dixon \& Ridley (1987) have emphasized the accretionary wedge character of the high pressure metamorphic sequences of the northwest Cyclades. Thus gabbroic-ultramafic associations that are embedded within the underthrust Apulian plate sequences might represent fragments of the floor of the Pindos Ocean that were incorporated into the wedge during a subduction-accretion process. A complementary problem is posed by similar ophiolitic associations found at higher levels within 'Upper Units' that overlie the high pressure rocks of the Cycladic Massif. Might they also 


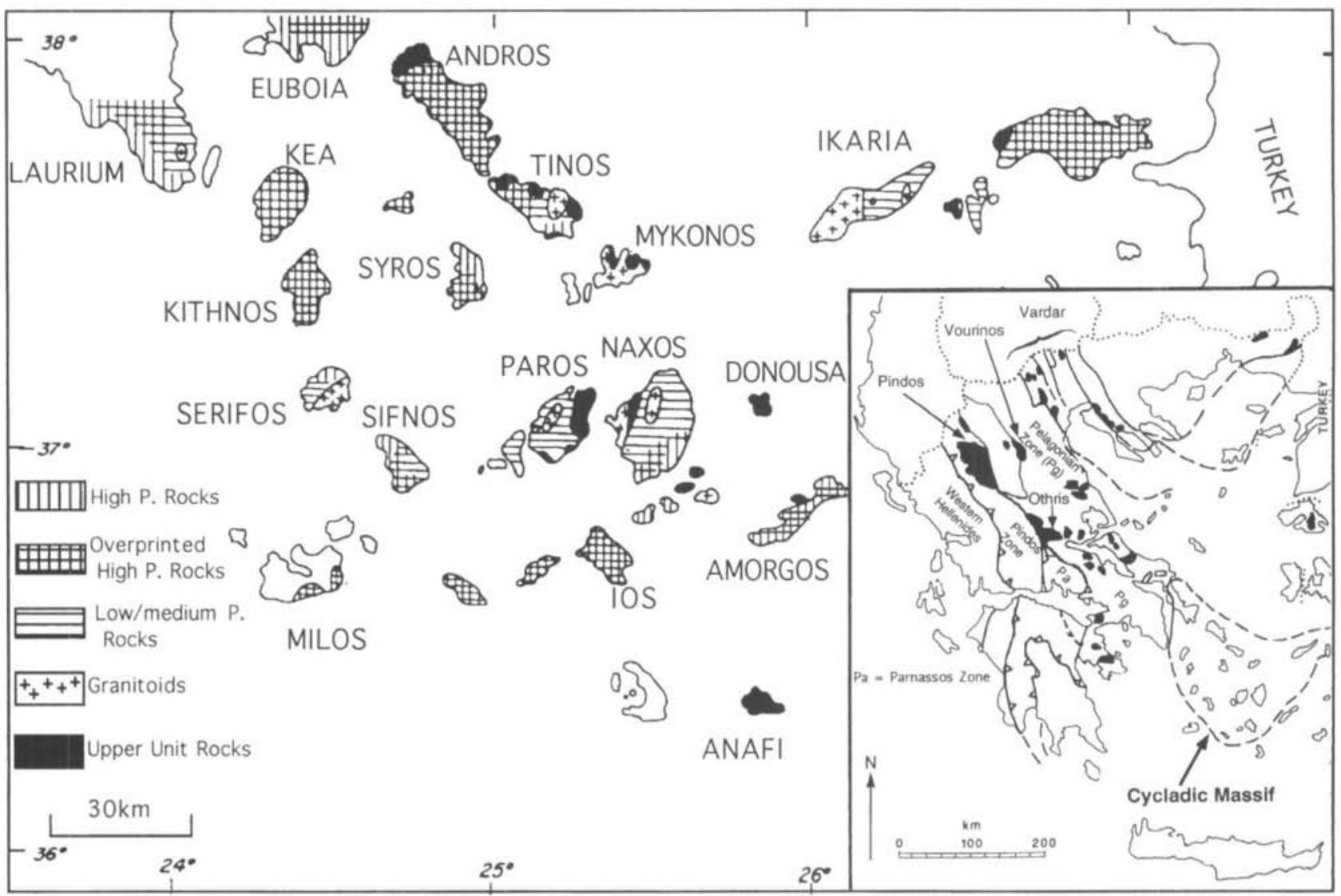

Figure 1. Geological map of the Cycladic massif (after Altherr et al. 1979, 1982) showing: rock sequences comprising the Cycladic Blueschist Unit (Eocene high pressure metamorphic rocks; Eocene high pressure metamorphic rocks overprinted by the Oligocene/Miocene low-medium pressure metamorphism; Oligocene/Miocene low-medium pressure metamorphic rocks); Oligocene/Miocene granitoids; undifferentiated rocks of the Upper tectonic Unit including the ophiolite exposures of Tinos. Inset: map of Greece showing the geotectonic zones and the locations of main outcrops of ophiolites (black areas; from Smith, 1993). Two parallel belts of ophiolites are distinguished. Ophiolites of the western belt are allochthonous, interpreted as having originated in the Pindos Ocean (Smith,Woodcock \& Naylor, 1979; Robertson et al. 1991). Eastwards, in the more internal parts of the Hellenides, another parallel belt of ophiolites is observed (Vardar Zone: Aubouin et al. 1970; Dewey et al. 1973), probably autochthonous (Smith, 1993).

represent obducted Pindoan sea-floor? The typical mode of occurrence of ophiolitic associations in the Cycladic Upper Unit is considered to be within low pressure metamorphosed melanges of late Cretaceous age, as on the island of Anafi (Reinecke et al. 1982). It greatly differs from that of the Eo-Hellenic ophiolites, which in the Cyclades are limited to the occurrence of serpentinized peridotites covered by early Cretaceous transgressive limestones on the island of Paros (Papanikolaou, 1980).

This paper focuses on the largest exposure of ophiolitic rocks in the Cyclades occurring on the island of Tinos (Fig. 1). Melidonis (1980) and Avigad (D. Avigad, unpub. Ph.D. thesis, Hebrew Univ. of Jerusalem, 1990) gave general descriptions of these rocks and noted that there was no petrological evidence for their having participated in the Eocene high pressure metamorphic phase. The exposures were described as a melange of meta-ophiolites by Bröcker (1990a) and Avigad (unpub. Ph.D. thesis), and were ascribed to an Upper tectonic Unit juxtaposed on top of the Alpine high pressure sequences by a low-angle normal fault (Avigad \& Garfunkel, 1989,
1991). The main aim of this study is to gain a detailed knowledge of the origin and tectono-metamorphic evolution of this unique rock-unit and to interpret its place within the framework of the Alpine orogeny in the Cyclades. We will show that the exposures of the Tinos Upper Unit represent a sliced and dismembered ophiolite complex which has undergone ocean-floor hydrothermal alteration followed by a pervasive regional metamorphic overprint in the greenschist facies. This history distinguishes it from both the high pressure and the unmetamorphosed ophiolitic suites in the Hellenides.

\section{Geological setting}

The Alpine orogen in the Cyclades comprises three tectono-metamorphic units separated by low-angle faults (Fig. 1) (Dürr et al. 1978a; Avigad \& Garfunkel, 1989). The lowermost Basal Unit is exposed in a single site on Tinos where weakly metamorphosed dolomites tectonically underlie the rocks of the Lower Unit. The overlying, most widespread Lower Unit (the Blueschist Unit) is mainly composed of a volcanic and sedimentary sequence 
which underwent regional eclogite- and blueschist-facies metamorphism during the Eocene (Altherr et al. 1979; Bröcker et al. 1993). In most localities, the rocks were fully overprinted by greenschist-facies assemblages at the Oligocene-Miocene boundary (Altherr et al. 1982; Schliestedt, Altherr \& Matthews, 1987). The peak $P-T$ conditions of the Eocene high pressure metamorphic event have been estimated at about $15 \mathrm{kbar}$ and $500^{\circ} \mathrm{C}$ (Matthews \& Schliestedt, 1984; Schliestedt, 1986; Bröcker et al. 1993; Matthews, 1994). Similar temperatures, but at pressures of 5-7 kbar, were estimated for the greenschist-facies overprint (Schliestedt \& Matthews, 1987; Avigad et al. 1992).

The Upper Unit, which tectonically overlies the Lower Unit, consists of both unmetamorphosed rocks and various sequences of low pressure metamorphic rocks. The low- $P$ metamorphic rocks are of late Cretaceous age and include granitic gneiss and amphibolite overlying pelitic greenschist on Syros (Ridley, 1984; Maluski, Bonneau \& Kienast, 1987), amphibolite and sillimanite gneiss on Nikouria (north Amorgos) and Donousa (Dürr et al. $1978 a, b)$ and granitic-ophiolitic melange on Anafi (Reinecke et al. 1982) and Crete (Seidel et al. 1981). The metamorphosed ophiolites on Tinos, dated as late Cretaceous (Patzak, Okrusch \& Kreuzer, 1994; D. Avigad, unpub. data), seem genetically related to this group of rocks.

The Upper Unit sequences were not metamorphosed at high pressures. The low-angle tectonic contact between the two units marks a significant metamorphic gap where a thick crustal section has been omitted. Avigad \& Garfunkel (1991), following other authors (Ridley, 1984; Lister, Banga \& Feenstra, 1984), argued that the exhumation of the Eocene Blueschist Unit from a depth of more than $50 \mathrm{~km}$ occurred by low-angle normal faults. These faults removed the overburden from above the blueschists, leaving thin remnants comprising the Upper Unit. Orogenic activity was terminated by extensive intrusion of granitoids during the Miocene (Altherr et al. 1982, 1988).

The island of Tinos, where the three tectono-metamorphic units and a Miocene granite are exposed, is a key area in understanding the structure of the Alpine orogen in the Cyclades (Fig. 2). The juxtaposition of the Upper tectonic Unit must have occurred in a relatively narrow time slot, limited on the one hand by the greenschistfacies metamorphic event dated at 23 to $21 \mathrm{Ma}$ (Bröcker et al. 1993) and by the intrusion of the 18-Ma-old granite (Altherr et al. 1982, 1988) that cuts across the tectonic contact between the Lower and Upper units (Avigad \& Garfunkel, 1989). The structure of Tinos as seen today was shaped by a Miocene or younger post-metamorphic phase of deformation that acted on all tectono-metamorphic units. Northeast-trending, large-scale (a few kilometres in places), gentle and upright folds allowed preservation of the Upper Unit in open synforms and exposed the Basal Unit and the granite in the core of antiforms.

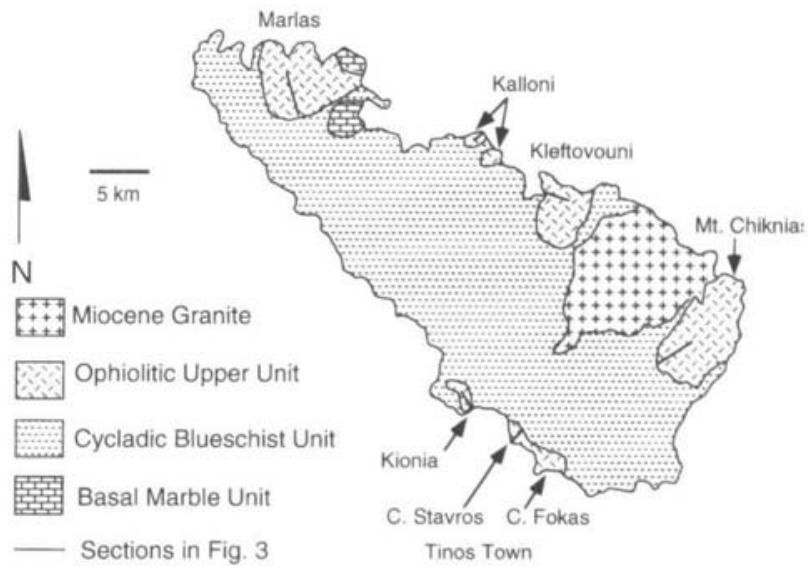

Figure 2. Geological map of Tinos showing the ophiolite exposures discussed in the text.

\section{Tectono-stratigraphy of the Tinos Ophiolite}

Six areas exposing ophiolitic rocks were studied in the present work. Schematic cross-sections of the exposures are given in Figure 3. They comprise three major rock types: (1) mafic phyllites whose texture and mineralogy (albite-epidote-actinolite-chlorite) indicate basaltic (perhaps pyroclastic) protoliths; (2) meta-gabbros, strongly uralitized and saussuritized, but exhibiting wellpreserved igneous textures; (3) serpentinites, mostly dark and massive, but sheared along tectonic contacts, where they are associated with talc and tremolite schists. In places the serpentinites are enriched in carbonates to form ophicalcite.

The following brief descriptions outline important features of the outcrops from the point of view of their assembly as parts of a dismembered ophiolitic complex. Detailed descriptions of the localities are given in Katz (Katzir) (unpub. M.Sc. thesis, Hebrew Univ. of Jerusalem, 1993).

Mt Chiknias. A 200-m-thick section outcrops on the higher slopes of Mt Chiknias on the eastern coast of Tinos (Figs 2,3). It is the largest outcrop of ophiolitic rocks on Tinos. Schistosity-parallel ductile shear zones divide the section into three different lithological slices (inset to Fig. 3): (1) a 50-m-thick basal slice dominated by mafic phyllites; (2) an intermediate slice composed of $60 \mathrm{~m}$ of massive serpentinites; and (3) an upper slice composed of $15 \mathrm{~m}$ of banded meta-gabbros overlain by $60 \mathrm{~m}$ of serpentinites.

The base of the phyllite slice is marked by lenses of tectonized antigorite serpentinite and talc. The rocks underlying the mafic phyllites consist of greenschists intercalated with quartzo-feldspathic rocks. It is not completely clear whether these underlying rocks belong to the Lower metamorphic Unit or are an additional tectonic slice forming part of the Upper Unit.

Blocks of amphibolite outcrop in the upper parts of the phyllitic section, and at the top of the section this amphibolite is highly tectonized and forms a continuous $1-\mathrm{m}$ thick layer as part of a narrow shear zone. The shear zone 


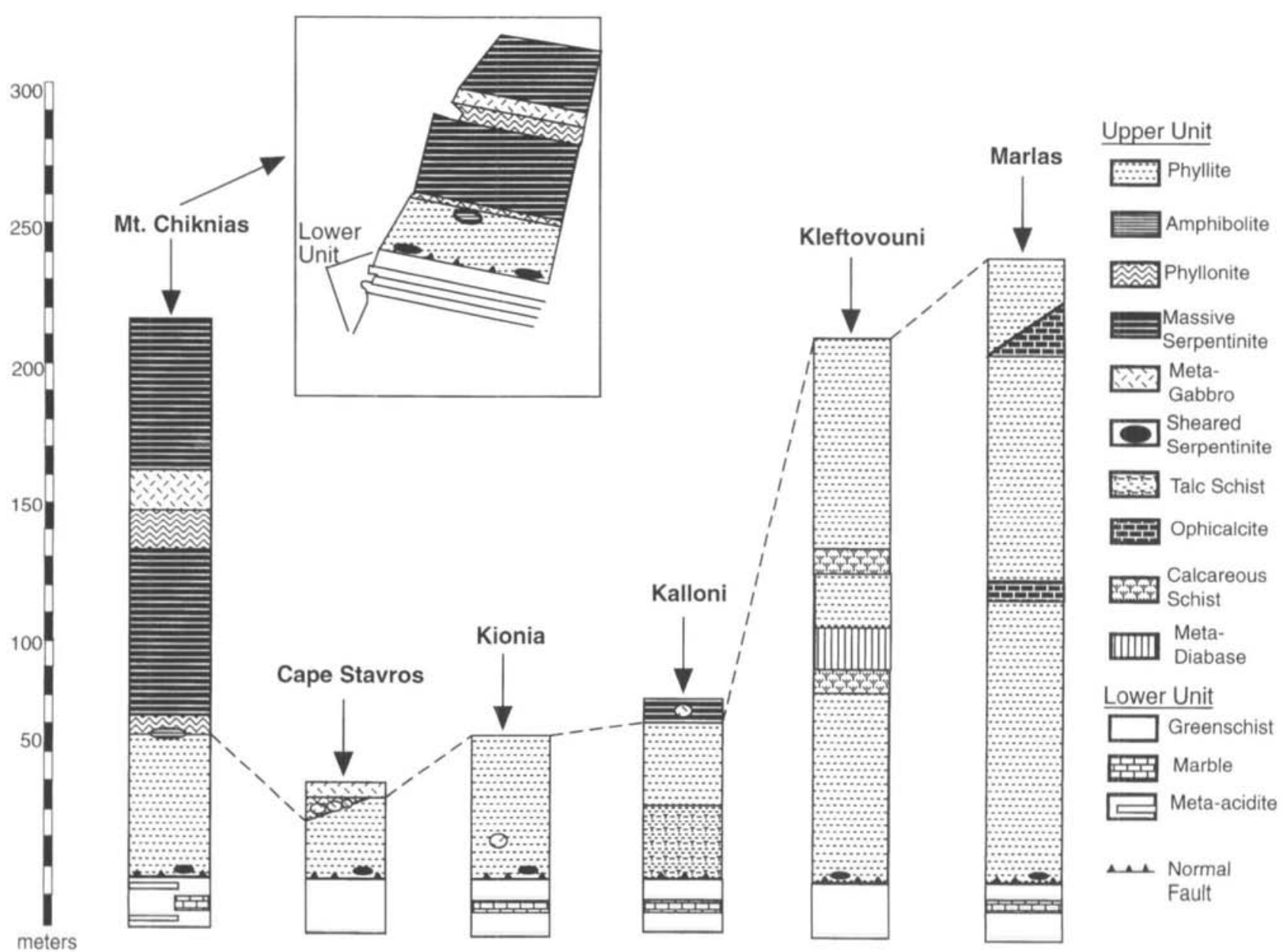

Figure 3. Lithological columnar sections of the six ophiolite outcrops studied in this work. Inset figure is a simplified cross-section of the exposure at Mt Chiknias.

also occurs in the serpentinites above in the form of a 3m-thick layer of sheared antigorite-tremolite-chlorite serpentinites. Above this shear zone occur green and dark massive serpentinites. The green varieties are antigorite serpentinites, whereas the dark types are olivine-bearing antigorite serpentinites. Podiform bodies of black chromite occur infrequently.

The massive serpentinites, which form prominent cliffs, are overlain by an eroded plateau which is the topographical expression of a 15-m-thick zone of sheared rocks, mainly phyllonites (upper sequence of phyllonites in Fig. 3). This shear zone consists of talc-chlorite phyllonite with porphyroclasts of amphibole, bounded from above and below by thin layers of metasomatized tremolite-rich rock. The upper horizon of tremolite-rich rocks grades into a coarser and more massive meta-gabbro of the upper slice.

The meta-gabbro consists mainly of dark green, long prismatic amphiboles in a white and opaque matrix consisting of saussurite (a microcrystalline aggregate of clinozoisite, chlorite and albite). Modal layering defined by alternation of light and dark components is conspicuous. Serpentinites, similar to those of the intermediate slice, overlie the gabbro (Fig. 3), with no evidence of deformation along the contact. Modal layering in gabbros and smooth transition from gabbros to serpentinites suggest an origin as crystal cumulates in an oceanic magma chamber.

Tinos town. Two different lithological sections occur in the area of Tinos town (Figs 2,3):

1. Cape Fokas. This meta-volcanic sequence consisting of interlayered albite-epidote amphibolites and quartzofeldspathic gneisses was studied in detail by Patzak, Okrusch \& Kreuzer (1994). K-Ar radiometric determinations on hornblendes yielded late Cretaceous ages.

2. Cape Stavros. The lowermost part consists of at least $20 \mathrm{~m}$ of partially mylonitized, finely laminated mafic phyllites. This is overlain by a tectonic melange zone of variable thickness $(0-8 \mathrm{~m})$ consisting of rounded blocks of metre-sized amphibolite- and greenschist-facies metabasites and meta-acidites surrounded by a matrix of highly sheared ultramafic material. Above this tectonic breccia is a 3-5-m-thick layer of banded uralitized metagabbro. The contact with the Lower Unit is characterized by a thin layer of talc serpentinite.

Kionia Hill. The $50 \mathrm{~m}$ ophiolitic section at Kionia Hill (Figs 2,3) is almost entirely formed of mafic and micaceous phyllites. Tremolite-talc-chlorite schist, several tens of centimetres thick, separates the Lower Unit from the phyllites. The base of the phyllite section consists of a 
2-m-thick sheared horizon of boudins and lenses (several centimetres in size) of medium-crystalline quartz and albite wrapped in a matrix of elongate muscovite and chlorite and mats of calcite. A prominent feature of this section is the occurrence of a $3-\mathrm{m}$-wide massive single block of coarse metabasic rock enclosed within the strongly foliated phyllites, with a thin tremolite-chlorite contact zone.

Marlas. The exposure near the village of Marlas, northwest Tinos (Figs 2,3), is mainly composed of green and grey mafic phyllites and ophicalcites. The ophicalcite is a matrix-supported breccia consisting of unsorted angular clasts of serpentinite set in a calcitic matrix. Metasomatic reaction zones, such as chlorite blackwall, are well developed at the phyllite-ophicalcite contact. Unfolding the seemingly chaotic section reveals an orderly sequence of ophicalcite horizons interbedded within the phyllite. The base of the Upper Unit in Marlas is usually characterized by a thin layer of antigorite serpentinite containing minor amounts of vesuvianite. At the eastern end of the outcrop, mica schists of the Lower Unit are concordantly overlain by mafic phyllites

Kalloni. The 60 -m-thick section is dominated by talc schists in its lower part and mafic phyllites at its upper half (Figs 2,3). The talc schist is intercalated with thin horizons of phyllite (0.1-1 m thick), serpentinites (2-3 m thick) and dark fissile chlorite-vesuvianite slates. The mafic phyllites are overlain by a several-metre-thick rusty-red serpentinite containing blocks of uralitized meta-gabbro. Intensive magnesite mineralization is conspicuous in the Kalloni section.

Kleftovouni. The section at Kleftovouni consists of a 200-m-thick pile of phyllites (Figs 2,3). The contact layer consists of $0.5-\mathrm{m}$-thick talc serpentinite. The section is disrupted by layers of calcareous schist (1-2 m thick) and by a 10-m-thick, almost non-schistose metamafic layer (flow? sill?), bounded by thin white tremolite at contacts.

From the above descriptions it is evident that, although differing in the sequence of rock-types, the Upper Unit outcrops on Tinos display the same overall structure (Fig. 3): tectonic slices separated by low-angle shear zones with mafic phyllites at the bottom, serpentinites and gabbros above. Narrow sheared layers of metamorphosed ultramafic rocks usually occur at the base of the Upper Unit. Comparison of the Tinos outcrops with a typical complete section of obducted oceanic lithosphere reveals the following observations. (i) The ultramafic, gabbroic, and basaltic members are represented on Tinos, but other, high-level components (the sheeted dykes and the sedimentary cover) are missing. The equivalence of the mafic phyllites with the tholeiitic basaltic member of the oceanic crust will be confirmed by geochemical means (see below, Section 6). (ii) The thicknesses of the exposed sections on Tinos are smaller by one or two orders of magnitude than complete ophiolite sections, which reach some $10 \mathrm{~km}$ (Nicolas, 1989). (iii) The classic ultramafic
(1) - mafic (2) - volcanic (3) stratigraphic order of the oceanic series is reversed on Tinos where we observe a disordered situation, e.g. the 3-1-2-1 order of $\mathrm{Mt}$ Chiknias. These observations are interpreted as showing that the rocks are parts of a dismembered ophiolite.

The occurrence of lenses and blocks in the phyllitic section, of melange zones composed of mafic blocks supported by ultramafic matrix, and of ophicalcites requires a mechanism of mixing. Mixing preceded or occurred contemporaneously with metamorphism as indicated by well-developed reaction zones and rims around the blocks and by the foliation in the country-rocks which wrap the enclosed rocks.

The late Cretaceous gneiss-amphibolite sequence at Cape Fokas is an exception, and has no lithological counterparts in the other exposures of the Upper Unit on Tinos. It was regionally metamorphosed at higher grade than most of the other rocks and is too thick to be correlated with the scarce thin amphibolites at Mt Chiknias and Cape Stavros. Moreover it contains quartzo-feldspathic rocks that are absent in the other exposures. It was assumed to overlie the Cape Stavros sequences (Bröcker,1990b). Similar field relations within the Upper Unit were found on southeastern Syros by Ridley (1984), where the quartzo-feldspathic Vari gneiss with some interbedded horizons of epidote amphibolite overlies mylonitized basic greenschist dotted with yellow epidote pods.

\section{Analytical methods}

The mineralogy of serpentine minerals was determined by X-ray powder diffraction using a Phillips PW 1730 diffractometer with copper $\mathrm{K} \alpha$ radiation. Discriminative criteria utilized for the identification of serpentine polymorphs were taken from Whittaker \& Zussman (1956).

Mineral chemistry of representative rock samples was determined by a Jeol JXA 8600 electron microprobe. Electron beam conditions were $15 \mathrm{keV}$ and $10 \mathrm{nA}$. The results were corrected by the ZAF method. Formulae calculations were based upon Robinson, Schumacher \& Spear (1982) and the 'ax' computer program (T. J. B. Holland, pers. comm.).

Whole rock chemical analyses were carried out using standard XRF methods. Fusion discs and powder pellets of ignited rock-powders plus $\mathrm{Li}_{2} \mathrm{~B}_{4} \mathrm{O}_{7}$ were analysed for major and trace element contents, respectively, in an automated X-ray fluorescence spectrometer (Phillips, PW 1404) at the University of Hannover, Germany. Accuracy is better than $2 \%$ for major elements; $10 \%$ for trace elements with abundances greater than $50 \mathrm{ppm}$, and $50 \%$ for abundances down to $1 \mathrm{ppm}$. Loss of ignition (LOI) has been determined gravimetrically and corrected for gain due to oxidation of iron. FeO has been determined by an oxidimetric method using $\mathrm{KMnO}_{4}$ titration.

Carbon dioxide for isotope analyses was extracted using standard techniques. Powders of silicate rocks were reacted with $\mathrm{BrF}_{s}$ at $600^{\circ} \mathrm{C}$ in nickel vessels (Clayton \& 
Mayeda, 1963), and the released oxygen was quantitatively converted to carbon dioxide by reaction with carbon at dull red heat. Carbonates (calcite) were reacted with ' $100 \%$ ' phosphoric acid at $25^{\circ} \mathrm{C}$ for 24 hours (McCrea, 1950; Wachter \& Hayes, 1985). Isotope analyses were performed on a VG Micromass 602 ES mass spectrometer. Oxygen isotope analyses are reported using the notation relative to the SMOW standard and carbon isotope analyses relative to the PDB standard. Errors on oxygen isotope analyses are estimated at $0.30 \%$ (silicates), $0.32 \%$ (carbonates), and those on carbon isotope analyses are $0.17 \%$ (J. Ganor, unpub. Ph.D. thesis, Hebrew Univ. of Jerusalem, 1991).

\section{Petrography, mineralogy, petrology and structures of the Tinos Ophiolite}

\section{5.a. Petrography, mineralogy and petrology of the principal rock-types}

\section{5.a.l. Phyllites}

The typical mineral assemblage of the mafic phyllites is that of greenschists: epidote-chlorite-albite-actinolite \pm muscovite \pm calcite \pm biotite-sphene-magnetite. Millimetric-scale alternation of green (chlorite- and actinolite-rich), yellow (epidote-rich) and white (albite-rich) thin laminae is the most prominent textural feature. Mineralogy and fine-grained texture suggest basic volcanic protoliths, either flows or pyroclasts. An additional textural characteristic of these mafic phyllites is the occurrence of $0.1-3-\mathrm{cm}$-long angular yellow pods of microcrystalline epidote. These aggregates are separated by narrow bands of albite, and in places are coated with thin opaque rims of very finely crystalline material. We interpret these angular pieces either as pseudomorphs after phenocrysts of plagioclase or as fragments of local tectonic breccias within basalts.

Subordinate micaceous phyllites have a typical assemblage of muscovite-chlorite-albite-quartz \pm calcite-magnetite-sphene and may represent shaly horizons within the dominantly volcanic protolith.

\section{5.a.2. Metagabbros}

Two major metagabbro types could be identified in the field: massive meta-gabbros forming continuous coherent layers (e.g. Chiknias, Tinos Town), and deformed blocks in phyllitic or ultramafic country rock (Kalloni, Kionia). The massive meta-gabbro layers are banded: amphiboles either form dark amphibole-rich bands or float in light bands of saussuritized plagioclase matrix. The amphiboles typically occur as idiomorphic pleochroic prisms (up to $7 \mathrm{~mm}$ long). Electron probe analyses show that these prisms are usually of magnesio-hornblende or pargasitic composition, surrounded by actinolitic rims (Fig. 4). Thin prisms and fibres of actinolitic-tremolitic amphibole clearly replace many broad prisms. These shreds, together with clinozoisite $(15-50 \%)$, chlorite $(5-20 \%)$

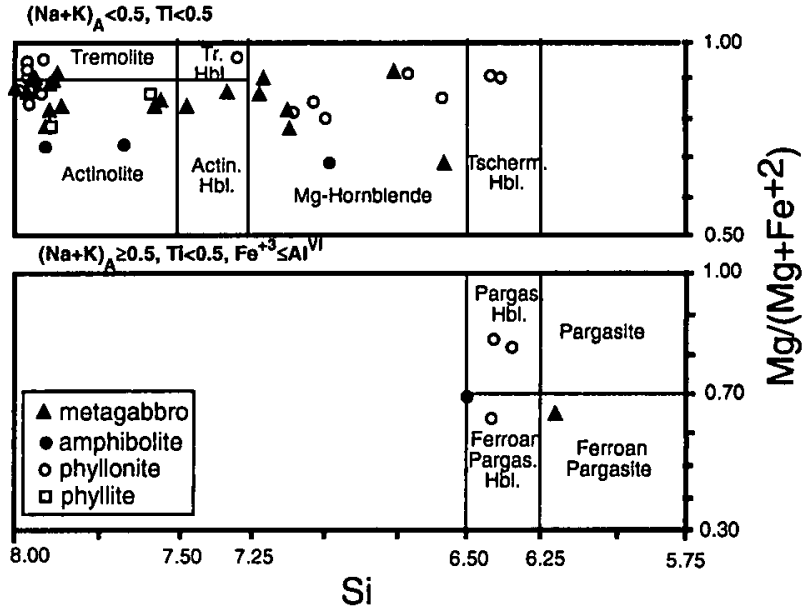

Figure 4. Electron microprobe analyses of amphiboles, classified according to Leake (1978). All amphiboles are calcic: $(\mathrm{Ca}+\mathrm{Na})_{B} \geq 1.34$ and $\mathrm{Na}_{B}<0.67$.

and albite (15-30\%), form the matrix of the meta-gabbro which also contains minor biotite and accessory sphene and ore. Xenomorphic relics of clinopyroxene occur as inclusions within some amphibole prisms, or more rarely as large xenomorphic crystals surrounded by continuous rings of chlorite and actinolite. An additional relic phase is chrome spinel. Generally, magmatic textures were preserved and gabbros have not acquired a visible metamorphic fabric, though actinolite in the matrix is not completely randomly oriented.

The wide compositional variety of the amphiboles suggests multi-stage metamorphism, though the fact that composition never exceeds the limit of calcic amphiboles as defined by Leake (1978) indicates relatively low pressure conditions during all stages of metamorphism. The matrix assemblage is typical of mafic rocks metamorphosed at the greenschist facies, but the high modal abundance of hornblende, pseudomorphic after pyroxene, indicates higher degree of metamorphism at temperatures above $600^{\circ} \mathrm{C}$ (Spear, 1981). The mineralogical zoning and microtextural relations thus indicate a retrograde sequence consisting of an earlier high grade event followed by a later greenschist-facies overprint. Pseudomorphism of pargasitic to tremolitic amphibole after clinopyroxene of augitic composition is characteristic of mid-ocean ridge gabbros (Ito \& Anderson, 1983), suggesting that the earlier high grade event occurred during ocean floor metamorphism.

The meta-gabbro blocks are composed of 1-1.5- $\mathrm{mm}$ long zoned prisms of calcic amphibole $(25 \%)$ set in a matrix of well oriented aggregates of microcrystalline epidote, fibrous chlorite and tremolite, laths of white mica, and minor granoblastic albite. The amphiboles are zoned from magnesio-hornblende and actinolitic hornblende to actinolite or tremolite (Fig. 4). The compositional range is much more restricted than in the meta-gabbro layers but tremolite clearly replaces former hornblende, and also joins other phases in the oriented matrix to suggest a syn-deformational event at the green- 
schist facies. This event is particularly prominent in the blocks often leaving only relic hornblende as evidence of an earlier high temperature history.

\section{5.a.3. Serpentinites}

The dominant serpentine polymorph of the serpentinites is antigorite, which constitutes $50-100 \%$ of the whole rock. The antigorite typically occurs as irregular equant, sometimes spherulitic, grains $(50-100 \mathrm{~mm})$, packed in a tight interlocking fabric. However, sometimes randomly oriented elongated plates of antigorite, at times up to $1.2 \mathrm{~mm}$ long blade-like crystals, dominate the rock, creating an interpenetrating fabric.

Olivine occurs as composite grains forming mosaics of small anhedral crystals which often overgrow areas enriched in fine-grained magnetite. This feature is accentuated where olivine has nucleated along parallel trains of magnetite grains (Fig. 5a). Electron probe analyses show that the olivine is almost end-member forsterite with Fo content ranging from 93 to $98 \%$ (Table 1). These Fo contents are higher than the typical olivine compositions of upper mantle peridotites $\left(\mathrm{Fo}_{88-93}\right)$, and show that the forsterites in the Tinos rocks are not relics, but are neoformed crystals coexisting with antigorite. The olivines show no systematic relation between their $\mathrm{MnO}$ content and olivine composition (Fig. 6). This contrasts with the olivines of mantle peridotites which define a narrow linear trend between the two variables (Vance \& Dungan, 1977). The high $\mathrm{Mn}$ values in the Tinos olivines reflect the strong partitioning of $\mathrm{Mn}$ into olivine relative to coexisting antigorite.

The antigorite and olivine overgrow earlier serpentine textures. Prismatic plates of bastite (lizardite pseudomorphs after pyroxenes), which sometimes mimic the cleavage of earlier pyroxene, are overgrown by antigorite and olivine (Fig. 5b). Less commonly, blades and plates of antigorite develop at the expense of a relic mesh texture with reddish-brown cores of brucite. Such mesh textures are typically formed where lizardite replaces olivine (Wicks \& Whittaker, 1977).

Carbonates (mostly magnesite, but sometimes calcite) occur infrequently as lenses of xenomorphic twinned crystals. Neoformed brucite occurs as scarce elongated
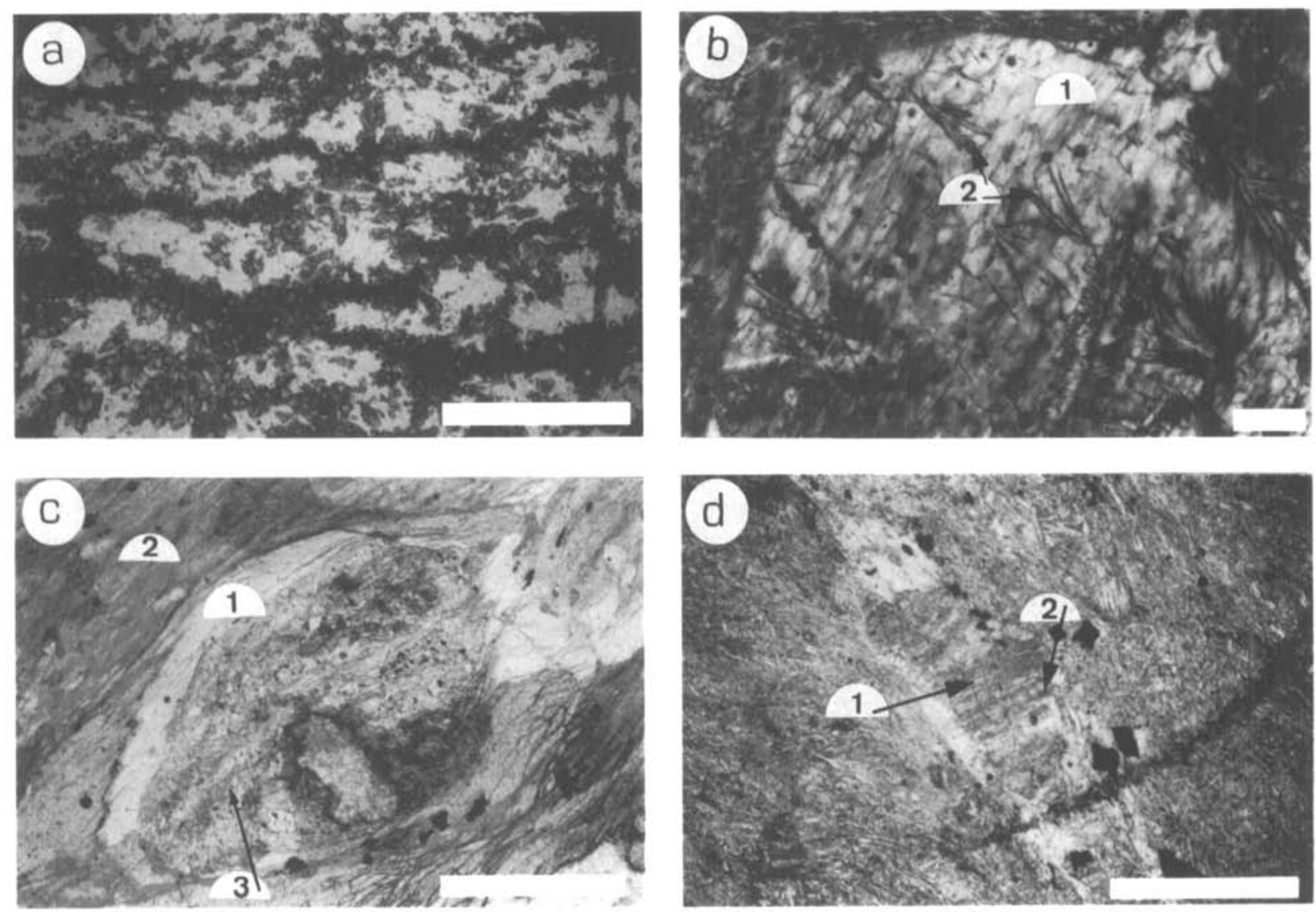

Figure 5. Photomicrographs of thin sections under the petrographic microscope. (a) Small anhedral crystals of olivine (cloudy tint; high relief) overgrowing parallel trains of magnetite in a low relief mat of antigorite (massive serpentinites, Mt Chiknias). (b) Prismatic plate of lizardite (1) (occupying most of the field of view), which mimics the cleavage of earlier pyroxene (bastite), is itself overgrown by 'feathers' and fibres of antigorite (2) (ophicalcite, Marlas). (c) Relic porphyroclast of high temperature amphibole with asymmetric tails of chlorite (1) (inner, light rim), talc and tremolite (2). Randomly oriented prisms of tremolite (3) overgrow the porphyroclast (phyllonite, Cape Stavros) . (d) Pulled-apart porphyroclast of high temperature pargasitic hornblende set in a sheared matrix of microcrystalline tremolite and talc. Tremolite (1) (light tone) has crystallized in the pulled-apart segments of the high temperature pargasitic hornblende (2) (dark tone) during or after deformation (phyllonite, Cape Stavros). Scale bars in photographs (a), (b), (d) $=1 \mathrm{~mm}$, in photograph (c) $=0.1 \mathrm{~mm}$. 
Table 1. Compositions of olivine in the serpentinites of Mt Chiknias

\begin{tabular}{|c|c|c|c|c|c|c|c|c|}
\hline Analysis no. & 1 & 2 & 3 & 4 & 5 & 6 & 7 & 8 \\
\hline \multicolumn{9}{|l|}{ Weight $\%$} \\
\hline $\mathrm{SiO}_{2}$ & 42.29 & 42.27 & 42.44 & 41.99 & 41.21 & 41.31 & 41.24 & 41.12 \\
\hline $\mathrm{FeO}^{-}$ & 6.60 & 5.15 & 5.84 & 4.49 & 5.79 & 2.36 & 1.98 & 2.38 \\
\hline $\mathrm{MnO}$ & 0.40 & 0.23 & 0.16 & 0.14 & 0.50 & 0.13 & 0.08 & 0.11 \\
\hline $\mathrm{MgO}$ & 51.95 & 53.32 & 52.69 & 53.97 & 52.90 & 55.46 & 56.37 & 55.63 \\
\hline Total & 101.24 & 100.97 & 101.23 & 100.61 & 101.43 & 99.26 & 99.67 & 99.24 \\
\hline \multicolumn{9}{|c|}{ Number of cations } \\
\hline $\mathrm{Si}$ & 1.01 & 1.00 & 1.01 & 1.00 & 1.00 & 0.987 & 0.981 & 0.983 \\
\hline $\mathrm{Fe}$ & 0.13 & 0.10 & 0.12 & 0.09 & 0.11 & 0.047 & 0.039 & 0.048 \\
\hline $\mathrm{Mn}$ & 0.01 & 0.005 & 0.003 & 0.003 & 0.01 & 0.003 & 0.002 & 0.002 \\
\hline $\mathrm{Mg}$ & 1.84 & 1.89 & 1.86 & 1.91 & 1.87 & 1.976 & 1.998 & 1.983 \\
\hline Total & 2.99 & 3.00 & 2.99 & 3.00 & 3.00 & 3.013 & 3.019 & 3.017 \\
\hline$\%$ Fo. & 93.5 & 95 & 94 & 95.5 & 94.5 & 98 & 98 & 98 \\
\hline
\end{tabular}

Analyses 1-5 from Y. Katz (Katzir), unpub. M.Sc. thesis, The Hebrew University of Jerusalem, 1993; analyses 6-8 from D. Avigad, unpub. Ph. D. thesis, The Hebrew University of Jerusalem, 1990.

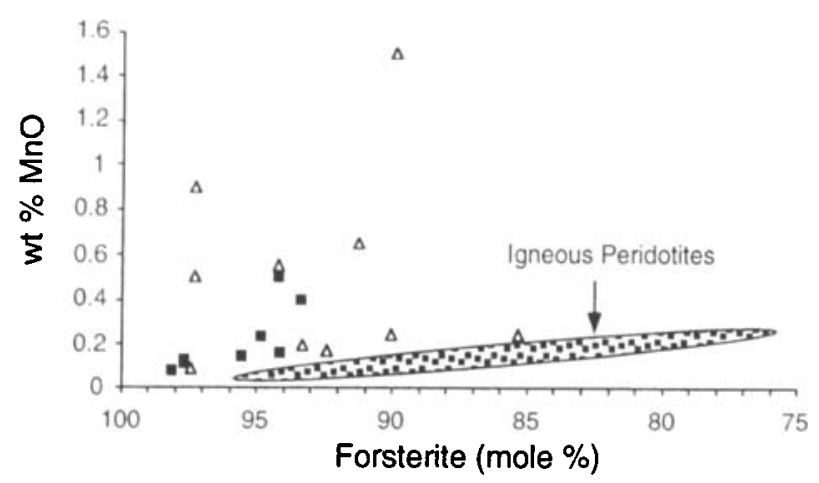

Figure 6. A plot of $\mathrm{MnO}(\mathrm{wt} \%)$ vs forsterite content of olivines (after Vance \& Dungan, 1977). Olivines from Tinos serpentinites (filled squares) plot similarly to metamorphosed forsterite-antigorite rocks from the Darrington and Sultan areas, Cascades Mountains (open triangles; Vance \& Dungan, 1977), i.e. they are randomly scattered and have high $\mathrm{MnO}$ content. For comparison the compositions of olivines from fresh igneous peridotites from the Cascades show a well-defined trend and relatively low $\mathrm{MnO}$ content (dotted area).

$(100 \mathrm{~mm})$ laths with creamy or anomalous brown interference colour. In addition to magnetite, idiomorphic cubes $(600-700 \mathrm{~mm})$ of deep brown chromite and/or chrome magnetite are present and in places they are associated with colourless (Mg-rich) long laths of chlorite.

Antigorite is recognized to be the higher grade variety of serpentine, whereas lizardite and chrysotile are generally the products of low temperature alteration (Trommsdorff \& Evans, 1974; Evans, 1977). The predominance of antigorite in the overgrowth textures, and the coexistence of antigorite with nearly pure forsterite, indicate that progressive metamorphism (deserpentinization) affected the massive serpentinites on Tinos. Relic bastite and mesh textures indicate a derivation from earlier lizardite serpentinite, which itself developed from olivine and pyroxene of the original peridotite.

Conditions for the metamorphic overprint in the serpentinites can be estimated from $T-P_{\mathrm{H}_{2} \mathrm{O}}$ and $T-X_{\mathrm{CO}_{2}}$ plots
(Fig. 7). Figure 7a is a $T-P_{\mathrm{H}_{2} \mathrm{O}}$ plot in the MSH system for equilibrium among the phases antigorite-bruciteforsterite-talc-anthophyllite, calculated using the program Thermocalc version 2.3 (Powell \& Holland, 1988; Holland \& Powell, 1990). Pressures are hardly constrained by the calculated reactions and possibly range within greenschist-facies conditions (2-9 kbar) deduced for the phyllites and meta-gabbros. The underlying greenschists of the Lower Unit were overprinted at pressures of 5-7 kbar prior to juxtaposition (Avigad et al. 1992), which may be considered as maximum pressures for the shallower-level serpentinites. At estimated pressures of $2-4 \mathrm{kbar}$, the stability field of antigorite + forsterite is limited to temperatures of $400-500^{\circ} \mathrm{C}$ by the reaction of antigorite + brucite to give forsterite and by the breakdown of antigorite to talc + forsterite. The occurrence of antigorite + forsterite + brucite or antigorite + forsterite + magnesite assemblages is governed by the reaction magnesite $+\mathrm{H}_{2} \mathrm{O} \rightarrow$ brucite $+\mathrm{CO}_{2}$ as shown by the calculated $T-X_{\mathrm{CO}_{2}}$ section at $3 \mathrm{kbar}$ (Fig. 7b). It can be seen that at $X_{\mathrm{CO}_{2}}$ above the invariant point of $T=418^{\circ} \mathrm{C}, X_{\mathrm{CO}_{2}}=$ 0.0015 , magnesite replaces brucite in the stable assemblage. The high temperature stability of antigorite remains the same in both assemblages. Because both assemblages exist in the massive serpentinites (although not all the four phases were observed to coexist at equilibrium) conditions are suggested to be close to those of the invariant point. This indicates that fluid conditions were internally buffered (i.e. no significant infiltration).

Therefore it is concluded that mafic phyllites, metagabbros and massive serpentinites in the Tinos ophiolite record the following history. Phyllites show metamorphism at greenschist-facies conditions, meta-gabbros record an initial high temperature phase of amphibole growth followed by a lower temperature greenschistfacies overprint; serpentinites show initial serpentinization of parent ultramafics followed by an overprint resulting in the formation of antigorite-forsterite. As will 
(a)

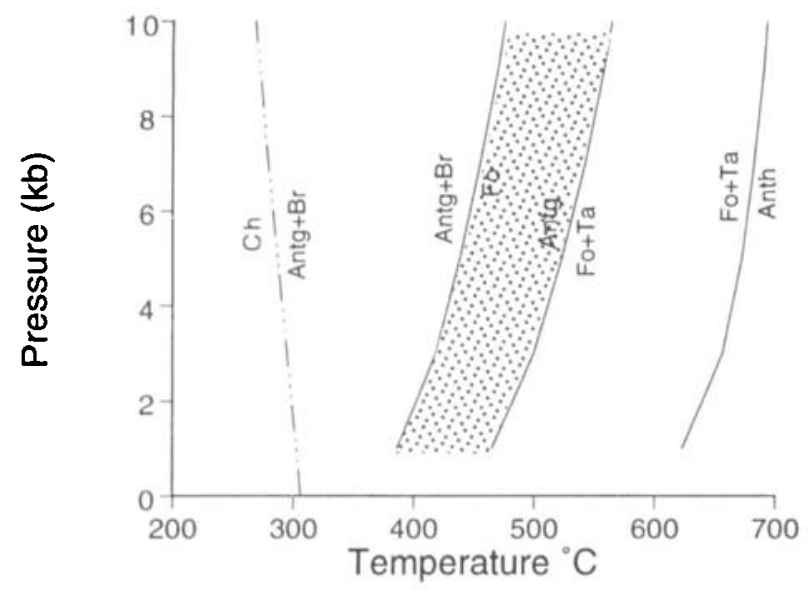

(b)

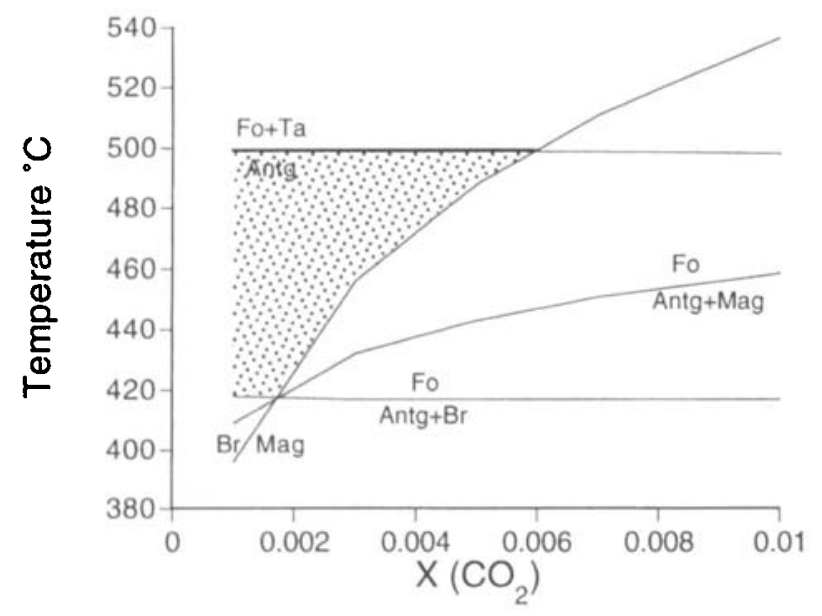

Figure 7. Calculated $T-P_{\mathrm{H}_{2} \mathrm{O}}$ and $T-X_{\mathrm{CO}_{2}}$ equilibria for serpentinites assemblages. (a) $T-P_{\mathrm{H}_{2} \mathrm{O}}$ plot in the MSH system defining upper and lower limits of the antigorite + forsterite assemblage (dotted area). (b) $T-X_{\mathrm{CO}_{2}}$ plot at assumed pressure of $3 \mathrm{kbar}$ showing the invariant point among the phases antigorite-forsterite-brucite-magnesite at $T=418^{\circ} \mathrm{C}$ and $X_{\mathrm{CO}_{2}}=0.0015$. Antigorite, forsterite and brucite coexist in the dotted area. Calculations are made using the program Thermocalc version 2.3 (Powell \& Holland, 1988; Holland \& Powell, 1990). The thermodynamic parameters for antigorite are obtained by the assumption: $a$ (antigorite $)=0.5 a$ (chrysotile) (Will, Powell \& Holland, 1990). The reaction line (dashed) chrysotile $\rightarrow$ antigorite + brucite is taken from Evans (1977). Abbrevations: Antg $=$ antigorite, $\mathrm{Anth}=$ anthophyllite, $\mathrm{Br}=$ brucite, $\mathrm{Ch}=$ Chrysotile, $\mathrm{Fo}=$ forsterite, $\mathrm{Mag}=$ magnesite, $\mathrm{Ta}=$ talc.

be discussed later, these observations can be correlated if one assumes that earlier sea-floor alteration history is overprinted by later regional metamorphic event at greenschist-facies conditions.

\section{5.b. Structures}

Structural analysis of the Tinos Upper Unit requires observations of both the large-scale structure and the small-scale penetrative deformation of the rocks.
The large-scale structure is of tens-of-metres-thick slices of different ophiolitic lithologies which do not follow the primary order of the ophiolite lithologies, sometimes repeating or reversing the original order. This order of the slices can be explained by dissection of the primary oceanic crust and the upper mantle by low-angle reverse faults. Such faults could have emplaced deep ultramafics upon shallower gabbros and even upon extrusives. Thrusting of ophiolite nappe, involving breaking of blocks to the fore-nappe environment (debris flows) may also explain the occurrence of amphibolite, meta-gabbro and serpentinite blocks within phyllites. Yet, in fully developed ophiolite complexes (e.g. Oman: Boudier, Ceuleneer \& Nicolas, 1988; Xigaze, Tibet: Girardeau, Marcoux \& Zao Yougong, 1984), such faults separate thrust sheets several times thicker than the slices in Tinos. The reverse faulting which explains the present order of the slices can not account for the absence of some primary components in the Tinos ophiolite, nor for the significant reduction in its thickness. In fact, it would thicken the sequence. Omission of gross portions of the ophiolite complex necessitates therefore either extensive erosion prior to thrusting, or normal faulting. One can hardly imagine that such erosion could have taken place before thrusting when the rocks were still submerged. The abundant tectonic dissection is more in line with a post-thrusting phase of normal faulting with flat-lying faults which cut out substantial parts of the original slice pile. Such extension agrees well with the normal faulting at the base of the Upper Unit deduced by Avigad \& Garfunkel (1991).

A rapid decrease in metamorphic grade from amphibolitic shear zone at the base of the massive serpentinites downwards to the phyllitic slice is observed at $\mathrm{Mt}$ Chiknias. It can be regarded as early, high temperature detachment of the ophiolitic slab after genesis at a spreading centre, causing a thermal aureole within the overthrusted rocks ('metamorphic sole'). This interpretation agrees with the above interpretation of the slices.

Ductile deformation structures are mainly developed within mafic phyllites and within the phyllonitic shear zones separating the slices. In the phyllites these fabrics are characterized by marked reduction in grain size, strong planar fabric, stretching lineation and $\delta$-type porphyroclasts of albite forming augen structures. Porphyroclasts also occur in the phyllonites at Mt Chiknias and Cape Stavros. Relic porphyroclasts of high temperature amphiboles have asymmetrical tails of talc and tremolite - the main phases in the matrix (Fig. 5c). The presence of pulled-apart porphyroclasts suggest that extensional strain parallel to the foliation was involved in the shearing (Fig. 5d). Grain size reduction in the phyllonite during ductile flow was generally accompanied by recrystallization and growth of talc, chlorite and tremolite producing the fine-grained, strongly oriented matrix. Alteration of porphyroclasts appears to have occurred later, after shear strain had ceased, as evidenced by the occurrence of randomly oriented, newly formed tremolite 
prisms (Fig. 5c). Because the deformed matrix and undeformed overgrowths consist of greenschist-facies minerals, we conclude that during shear, and at least for a short period afterwards, the rocks were at greenschist-facies conditions.

The penetrative deformation of the phyllites produced subhorizontal foliation, parallel to the compositional layering. This layer-parallel cleavage is occasionally folded by northeast-trending tight folds with wavelengths of a few centimetres to a few metres. Average trends of fold axes vary from $045^{\circ}$ at $\mathrm{Mt}$ Chiknias to $060^{\circ}$ at Kionia Hill and Cape Stavros; at Marlas, where the folds are best displayed, the axes trend $020^{\circ}$.

Age relations between the deformational events which produced the large-scale structure, the ductile shear micro-structures and the foliation can not be inferred from the limited field evidence. The late Cretaceous age determined in hornblendes separated from amphibolites (Patzak, Okrusch \& Kreuzer, 1994) and meta-gabbros (D. Avigad, pers. comm.) can be interpreted as the cooling age of the regional metamorphic event which produced the foliation. The ductile fabrics might represent either the early oceanic thrusting or the inferred Tertiary normal faulting. The observation that greenschist-facies conditions prevailed during and after the developing of the ductile fabrics seemingly favours the first alternative. In this case thrusting preceded and/or occurred contemporaneously with the late Cretaceous regional event. However, ductile shear structures related to Tertiary extension and juxtaposition of Upper Unit rocks on top of exhumed blueschists are also well known in the Cyclades (Buick, 1991; Lee \& Lister, 1992; Gautier \& Brun, 1994). The question of the age relationship between different types of structures and particularly the nature of the ductile fabrics remains open for future geochronological and structural studies.

\section{Geochemistry}

\section{6.a. Major and trace element geochemistry}

Representative major element chemical data for massive serpentinites, mafic phyllites, and amphibolites are given in Table 2. Allowing for the metasomatic effects of serpentinization, the $\mathrm{MgO}(46-48 \mathrm{wt} \%)$ and $\mathrm{SiO}_{2}$ (43.5-45.5 wt\%) contents and Mg-numbers (92) of the massive serpentinites resemble those of harzburgites or dunites rather than lherzolites. Characterization of the mafic phyllites and amphibolites on a TAS $\left(\mathrm{Na}_{2} \mathrm{O}+\mathrm{K}_{2} \mathrm{O}\right.$ vs $\mathrm{SiO}_{2}$ ) diagram for basalts (Le Bas et al. 1986) show that they straddle both the tholeiitic and alkaline basalt fields. However, Vallance (1974) has shown that spilitic

Table 2. Representative major and trace element XRF analyses of rocks of the Upper Unit on Tinos

\begin{tabular}{|c|c|c|c|c|c|c|}
\hline & $\begin{array}{c}\text { TC 7 } \\
\text { massive } \\
\text { serpentine }\end{array}$ & $\begin{array}{l}\text { TK } 17 \\
\text { mafic } \\
\text { phyllite }\end{array}$ & $\begin{array}{c}\text { TT } 47 \\
\text { mafic } \\
\text { phyllite }\end{array}$ & $\begin{array}{l}\text { TT } 42 \\
\text { mafic } \\
\text { phyllite }\end{array}$ & $\begin{array}{l}\text { TC } 99 \\
\text { mafic } \\
\text { phyllite }\end{array}$ & $\begin{array}{c}\text { TC } 103 \\
\text { amphibolite }\end{array}$ \\
\hline \multicolumn{7}{|c|}{ Major oxides (wt \%) } \\
\hline $\mathrm{SiO}$ & 40.8 & 49.6 & 47.0 & 45.7 & 46.7 & 50.4 \\
\hline $\mathrm{TiO}_{2}^{2}$ & 0.04 & 1.84 & 1.22 & 2.45 & 2.40 & 1.22 \\
\hline $\mathrm{Al}_{2}^{2} \mathrm{O}_{2}$ & 0.39 & 17.0 & 17.3 & 18.1 & 14.4 & 13.4 \\
\hline $\mathrm{Fe}_{2} \mathrm{O}_{3}$ & 3.66 & 8.24 & 6.08 & 10.4 & 3.72 & 2.38 \\
\hline $\mathrm{FeO}^{-3}$ & 2.74 & 2.74 & 2.73 & 2.29 & 7.79 & 6.98 \\
\hline $\mathrm{MnO}$ & 0.13 & 0.16 & 0.14 & 0.14 & 0.22 & 0.19 \\
\hline $\mathrm{MgO}$ & 41.5 & 4.34 & 5.83 & 4.59 & 7.87 & 9.73 \\
\hline $\mathrm{CaO}$ & 0.1 & 6.42 & 11.2 & 6.75 & 9.53 & 7.23 \\
\hline $\mathrm{Na}_{2} \mathrm{O}$ & 0.24 & 5.04 & 3.16 & 2.94 & 3.16 & 3.78 \\
\hline $\mathrm{K}_{2} \mathrm{O}$ & 0 & 0.59 & 0.79 & 2.99 & 0.21 & 0.41 \\
\hline $\mathrm{P}_{2} \mathrm{O}_{\mathrm{s}}$ & 0 & 0.21 & 0.11 & 0.26 & 0.3 & 0.20 \\
\hline LOI & 9.4 & 2.8 & 3.8 & 3.1 & 3.0 & 3.3 \\
\hline Total & 99.0 & 99.0 & 99.4 & 99.71 & 99.3 & 99.2 \\
\hline \multicolumn{7}{|c|}{ Trace elements (ppm) } \\
\hline $\mathrm{Ba}$ & 23 & 58 & 80 & 133 & - & 56 \\
\hline $\mathrm{Ce}$ & - & 26 & 14 & - & 30 & 25 \\
\hline Co & 97 & 42 & 40 & 39 & 39 & 48 \\
\hline $\mathrm{Cr}$ & 2728 & 207 & 339 & 140 & 196 & 432 \\
\hline Gd & 2 & 4 & 3 & 4 & 4 & 3 \\
\hline $\mathrm{La}$ & - & 2 & 13 & 10 & 5 & 15 \\
\hline $\mathrm{Nb}$ & 10 & 0 & 1 & 0 & 0 & 17 \\
\hline $\mathrm{Nd}$ & - & 18 & 9 & - & 20 & 13 \\
\hline $\mathrm{Ni}$ & 2312 & 104 & 117 & 79 & 113 & 280 \\
\hline Pr & 2 & 2 & 4 & 4 & 3 & 5 \\
\hline $\mathbf{R b}$ & 2 & 11 & 13 & 50 & 5 & 10 \\
\hline $\mathrm{Sm}$ & 2 & 5 & 3 & 5 & 4 & 3 \\
\hline $\mathrm{Sr}$ & 1 & 141 & 187 & 164 & 153 & 82 \\
\hline Th & 0 & 3 & 1 & 0 & 3 & 1 \\
\hline U & 2 & 2 & 1 & 0 & 0 & 2 \\
\hline V & 18 & 249 & 222 & 318 & 334 & 195 \\
\hline$Y$ & 2 & 41 & 27 & 54 & 53 & 25 \\
\hline $\mathrm{Zr}$ & 11 & 146 & 88 & 200 & 213 & 99 \\
\hline
\end{tabular}


degradation of a tholeiitic basalt could account for the altered rock having an apparent alkaline chemistry. Thus a 'first-order' chemical classification shows a resemblance between Tinos rocks and an oceanic suite, with volcanics showing tholeiitic affinities modified by spilitic degradation.

A more detailed insight into the nature of the protoliths is given by study of trace element abundances, preferably those immobile during alteration and metamorphism. Representative data are given in Table 2 and the more indicative trends are summarized in Figures 8,9 and 10.

The effects of magmatic differentiation in basic rocks are well seen where a less incompatible $(D \sim 0.1)$ element as Ti is plotted against more incompatible $(D<0.01)$ elements such as $\mathrm{Zr}$ and $\mathrm{Y}$ (Pearce \& Cann, 1973; Fig. 8a). It is possible to use this diagram to make a broad distinction between alkalic, calc-alkalic and tholeiitic basalts, and at least partially to distinguish island arc tholeiites (IAT) from mid-ocean ridge basalts (MORB). The Tinos mafic phyllites and amphibolites plot in the B field, common to MORB and IAT (Fig. 8a). A similar discriminatory ternary plot $\mathrm{MnO}-\mathrm{TiO}_{2}-\mathrm{P}_{2} \mathrm{O}_{5}$ (Mullen, 1983) is given in Figure $8 \mathrm{~b}$. The Tinos volcanics are scattered on the diagram and although they range over four different fields, including MORB, IAT, ocean island alkali basalts (OIA) and ocean island tholeiites (OIT), they clearly show an oceanic affinity, rather than an orogenic one. A third diagram for rocks of basaltic composition, a $\mathrm{TiO}_{2}$ vs $\mathrm{Al}_{2} \mathrm{O}_{3} / \mathrm{TiO}_{2}$ plot, is given in Figure 9a (Beccaluva et al. 1983). This diagram discriminates between MORB (high-Ti), IAT (low-Ti) and calk-alkaline basalts (CAB; very-low-Ti). The Tinos phyllites plot within the high-Ti basalts, consistent with a MORB source.

The above discriminations confirm that the mafic phyllites are oceanic tholeiitic basalts, yet the exact tectonic setting of their formation might only be established by using full patterns of trace element abundances. Figure 10 shows MORB normalized geochemical patterns for a selected range of incompatible elements of four samples of mafic phyllites and one sample of amphibolite. All five samples show selective enrichment in the mobile elements $(\mathrm{Sr}, \mathrm{K}, \mathrm{Rb}, \mathrm{Ba})$ and a relative lack of enrichment in the high-field strength elements (Ce, P, Zr, Sm, Ti, Y). Three samples show prominent Nb depletion. Such patterns are characteristic of tholeiites from intra-oceanic arcs (IAT: Pearce, 1983) and some marginal basin basalts (Saunders \& Tarney, 1984), where melts are generated in a mantle affected by subduction. The selective enrichments are thought to be caused by transport of the elements with the lowest ionic potential (i.e. mobile) via aqueous fluids from the subduction zone to the overlying zone of mantle melting (Saunders \& Tarney, 1979). The marked depletion in $\mathrm{Nb}$ is similar to that found in island arc tholeiites from the early stages of subduction (Wood et al. 1980; Mattey, Marsh \& Tarney, 1980). Whereas all the enriched elements are also mobile during alteration and metamorphism (Saunders \& Tarney, 1984), depletion in $\mathrm{Nb}$, a notable immobile high-field-strength element, is

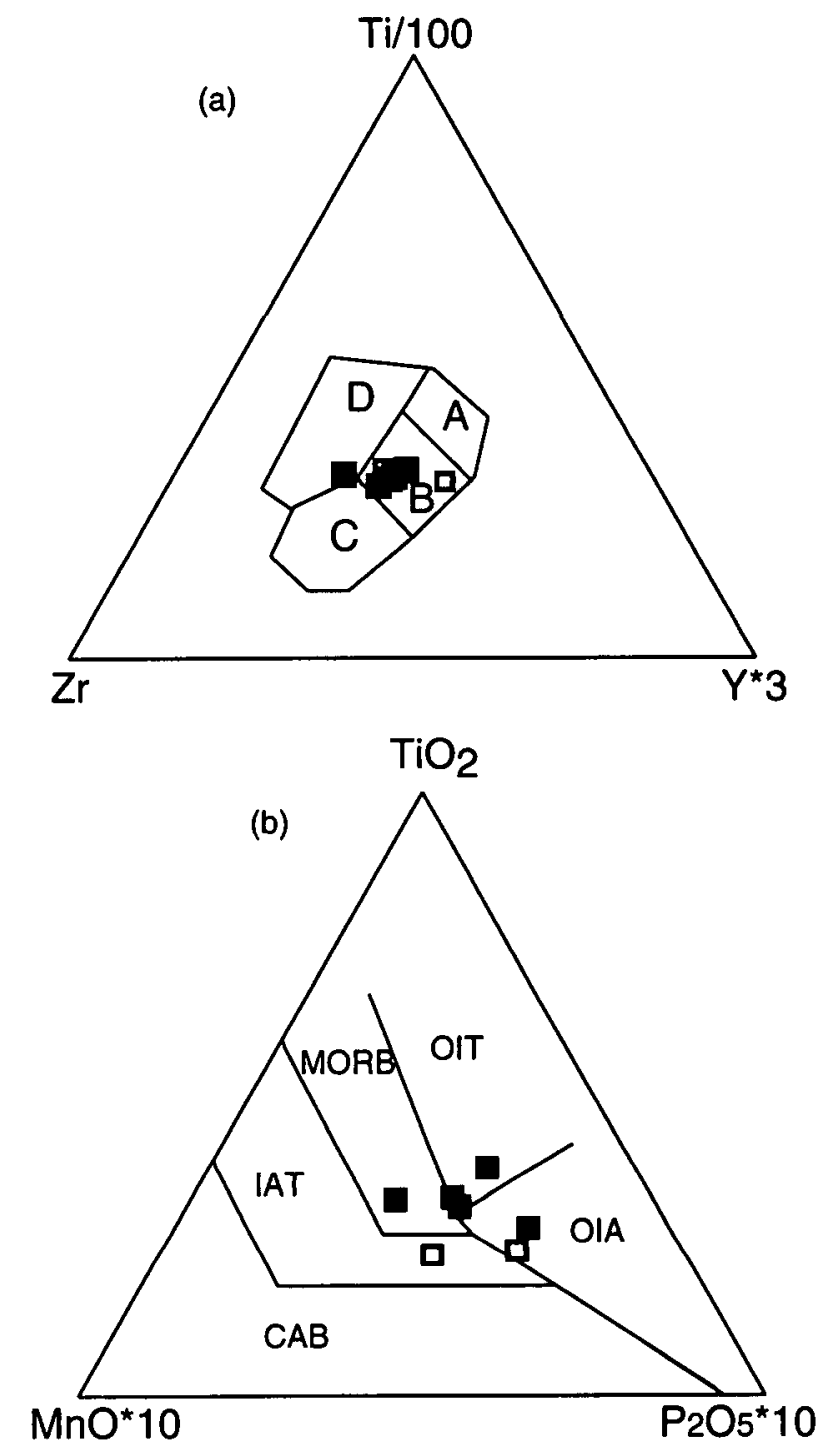

Figure 8. (a) Triangular Ti/100-Zr-Y*3 (Pearce \& Cann, 1973) and (b) $\mathrm{TiO}_{2}-\mathrm{MnO}^{*} 10-\mathrm{P}_{2} \mathrm{O}_{5} * 10$ (Mullen, 1983) discrimination diagrams for Tinos mafic phyllites (filled squares) and amphibolites (open squares). Fields in $\mathrm{Ti}-\mathrm{Zr}-\mathrm{Y}$ plot: $\mathrm{B}=\mathrm{MORB}, \mathrm{A}$ and $\mathrm{B}=\mathrm{IAT}, \mathrm{B}$ and $\mathrm{C}=$ calc-alkaline basalts, $\mathrm{D}=$ within plate basalts.

probably related to primary magmatic processes, hence verifying the supra-subduction zone (SSZ) affinity of Tinos mafic phyllites.

Figure 9a also includes model tie-lines (dashed lines) that link basaltic parental melt with ultramafic residua produced by different degrees of partial melting. The anticipated residual mantle rock after melting of high-Ti basalts would be lherzolite, whereas three out of four analyses of Tinos serpentinites plot closer to the harzburgite + dunite field. This suggests that higher degrees of partial melting than those calculated for MORB were needed to produce Tinos meta-volcanic rocks, well corresponding with their inferred supra-subduction zone origin (Pearce, Lippard \& Roberts, 1984). A further attempt to characterize the peridotitic origin of the serpentinites is given in Figure 9b, where the PRIMA normalized average $3 \mathrm{~d}$ transition 


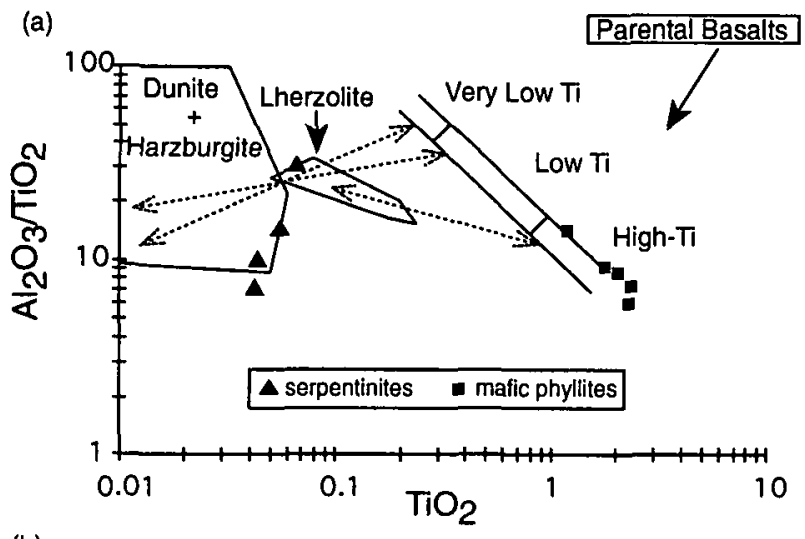

(b)

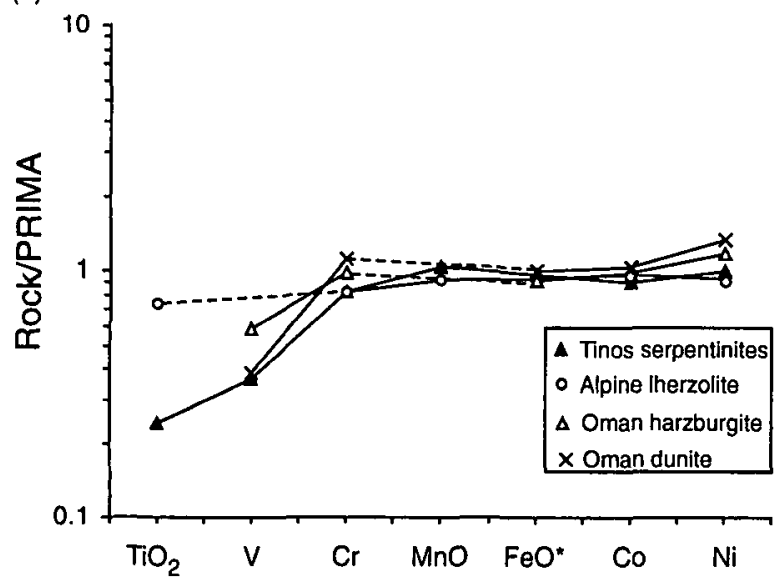

Figure 9. (a) $\mathrm{TiO}_{2}$ vs $\mathrm{Al}_{2} \mathrm{O}_{3} / \mathrm{TiO}_{2}$ discrimination diagram (after Beccaluva et al. 1983). Tinos phyllites plot in the range of highTi basalts. Also shown on the plot are the data for serpentinites: three of the serpentinite samples plot in the field of harzburgite + dunite and only one in the field of Iherzolite. Dashed lines connect the basaltic parental melts with the residua after partial melting, as modelled by Beccaluva et al. (1983). (b) Average 3d transition element compositions of Tinos serpentinites compared to those of an average Alpine lherzolite (data from Ottonello, Ernst \& Joron, 1984) and harzburgite and dunite from the Samail ophioloite, Oman (data from Boudier \& Coleman, 1981). All data are normalized to primordial mantle composition (PRIMA; Jagoutz et al. 1979).

element geochemistry of the Tinos serpentinites is compared to that of an average Alpine lherzolite (Ottonello, Ernst \& Joron, 1984) and harzburgite and dunite from the basal section of Samail ophiolite, Oman (Boudier \& Coleman, 1981). The Tinos serpentinites plot closest to patterns of harzburgite and dunite as noted in Figure $9 \mathrm{a}$ but are depleted in $\mathrm{Ti}$ and $\mathrm{V}$ relative to fresh ultramafic rocks, possibly as a result of hydration reaction.

Trace element data of meta-volcanic rocks and harzburgitic origin of meta-serpentinites thus suggest a suprasubduction zone affinity for Tinos ophiolitic slices. The occurrence of chromite pods within serpentinites (Pearce, Lippard \& Roberts, 1984) supports this conclusion.

\section{6.b. Stable isotope geochemistry}

Petrographic, mineralogical and chemical data presented in previous sections have shown that the parent igneous

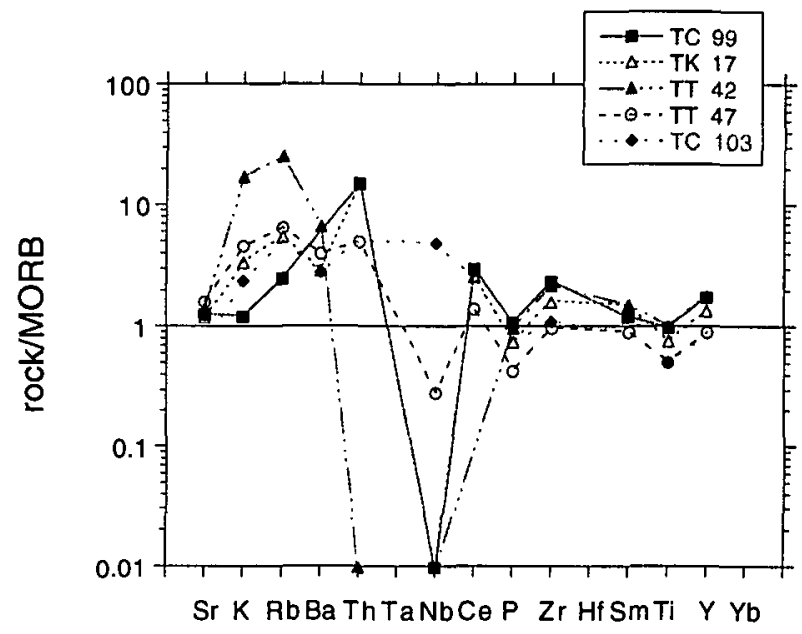

Figure 10. MORB-normalized spider diagrams of mafic phyllites from Mt Chiknias (TC 99), Kionia (TK 17), Cape Stavros (TT 42, TT 47) and amphibolite from Mt Chiknias (TC 103). Normalizing values are taken from Pearce (1983).

rocks underwent hydration. The alteration could potentially be a result of the high permeability of young seafloor allowing sea-water to penetrate and hydrothermally react with the rocks, or of submarine weathering (Gregory \& Taylor, 1981; Stakes \& O’Neil, 1982; Alt, Muehlenbachs \& Honnorez, 1986). Alternatively, the greenschist metamorphic event may have involved hydration (as in the case of alteration of meta-gabbro) or dehydration (deserpentinization). Oxygen isotope analyses have been shown to be powerful indicators of the nature of fluid-rock interaction in ophiolitic suites (e.g. Wenner \& Taylor, 1973; Gregory \& Taylor, 1981; Muehlenbachs, 1986; Burkhard \& O'Neil, 1988), and in this section we will attempt to characterize the $\delta^{18} \mathrm{O}$ 'signatures' of the various components of the Tinos rocks for their implications for fluid-rock interactions.

Oxygen isotope compositions of whole rock samples of serpentinites, mafic phyllites, gabbros, and sheared tectonic contacts are summarized in Figure 11. The results are plotted in two groups: Mt Chiknias samples, and samples from other exposures (Kalloni, Marlas). The grouping is made because the Chiknias samples appear to have distinctly lower $\delta^{18} \mathrm{O}$ values than samples from the other exposures which show no differences from one another. The distinction is particularly marked for the massive serpentinite exposures at Chiknias with $\delta^{18} \mathrm{O}$ between 5.2 and $8.2 \%$ (the highest value in an ophicalcite) and those of Marlas and Kalloni with $\delta^{18} \mathrm{O}$ varying from 10.5 to $13.5 \%$. These differences in $\delta^{18} \mathrm{O}$ values are also marked in the calcite component of ophicalcite samples. The serpentine fragment of an ophicalcite sample from Chiknias has a $\delta^{18} \mathrm{O}$ of $8.2 \%$, whereas the Marlas samples give serpentine values of around $12 \%$. Correspondingly the calcite matrices of these ophicalcites differ: Chiknias $\delta^{18} \mathrm{O}=$ $12.3 \%$; Marlas $\delta^{18} \mathrm{O}=17.8$ and $17.5 \%$. The $\delta^{13} \mathrm{C}$ values of these calcites are in the range 2.0 to $3.2 \%$, i.e. in the marine sedimentary range, yet the $\delta^{18} \mathrm{O}$ values are clearly not those of metasedimentary marbles, which have $\delta^{18} \mathrm{O}$ 


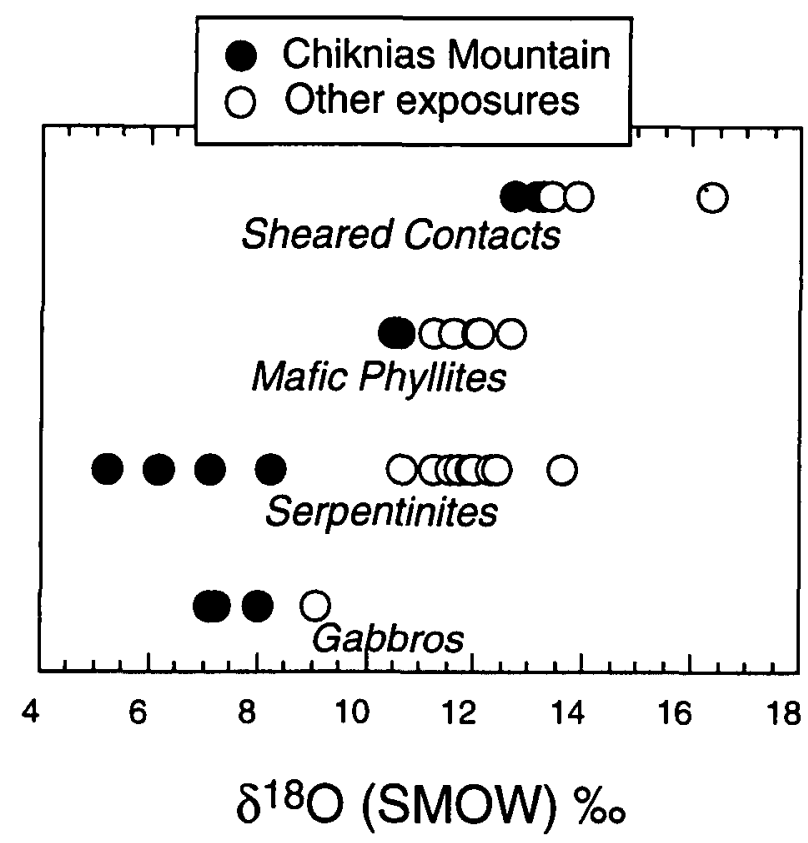

Figure 11. Distribution of $\delta^{18} \mathrm{O}$ values of whole rock samples of gabbros, serpentinites, mafic phyllites and sheared rocks from tectonic contacts.

values of 27 to $28 \%$. Thus even if these ophicalcites originated as breccias at the sea-floor (Bernoulli \& Weissert, 1985) they undoubtably underwent isotopic exchange with the associated ultramafic rocks during their metamorphic history.

The igneous protoliths of the metamorphosed ophiolites are all mantle-derived rocks with original $\delta^{18} \mathrm{O}$ values close to that of unaltered MORB, $5.7 \pm 0.2 \%$ (Taylor, 1968; Kyser, O'Neil \& Carmichael, 1982). The $\delta^{18} \mathrm{O}$ values for the Tinos ophiolites show an unusually and unique large variation from 5 to $17 \%$, and clearly indicate that the rocks have experienced a post-igneous alteration history.

A simple way to account for the distribution of $\delta^{18} \mathrm{O}$ values in the Tinos samples would be to assume that they were affected by low temperature alteration, with the less permeable gabbros and massive serpentinites at Chiknias being less affected (i.e. lower water/rock ratio). This process is examined in model mass-balance calculations in Figure 12 in which the variation of $\delta^{18} \mathrm{O}$ of a spilitized basic rock and an ultramafic rock interacting with seawater are plotted as a function of temperature for water/rock (W/R) $\delta^{18} \mathrm{O}$ ratios of $0.01,0.1,1$ and $\infty$. The calculations assume single-pass open system exchange (Taylor, 1977), and initial (pre-interaction) $\delta^{18} \mathrm{O}$ values of $0 \% o$ and $5.8 \%$ for the water and rock respectively. For spilitized basic rock, the rock-water fractionation is approximated by that of feldspar $\left(A n_{60}\right)$-water, because this feldspar composition is quite close to the chemical analysis of the mafic phyllites. The temperature coefficients for this fractionation are taken from O'Neil \& Taylor (1967) and for serpentine-water from Wenner \& Taylor (1973).
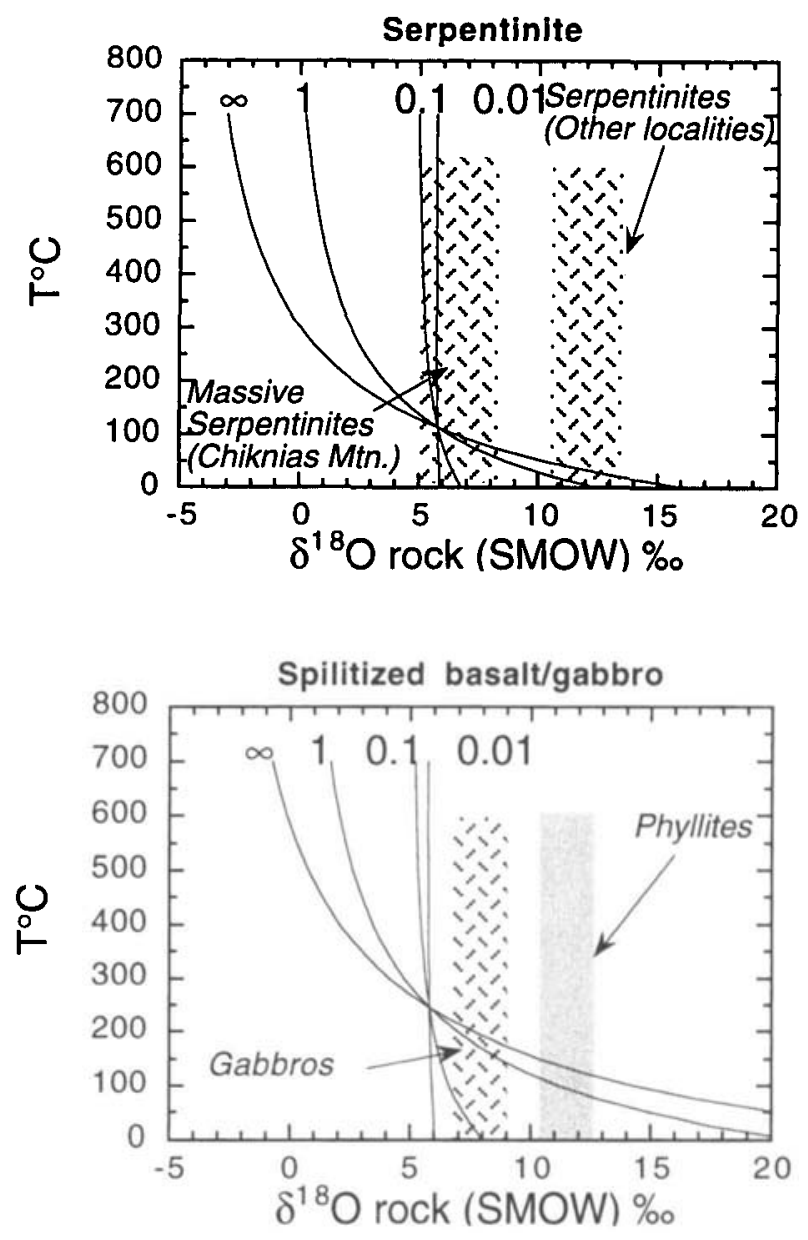

Figure 12. Model calculations of the variation of $\delta^{18} \mathrm{O}$ of altered serpentinite (a) and spilitized basalt/gabbro (b) as a function of temperature and water/rock (W/R) ratio. Initial conditions are assumed to be $\delta^{18} \mathrm{O}$ rock $=5.8 \%$ and $\delta^{18} \mathrm{O}$ water $=0 \%$. The calculations assume open system conditions (Taylor, 1977). The $\delta^{18} \mathrm{O}$ ranges observed for Tinos rocks are shown, represented by shaded areas.

The ranges of $\delta^{18} \mathrm{O}$ of Tinos mafic phyllites, gabbros and serpentinites are superimposed on the plots and lead to the following interpretations: (1) massive serpentinites at Chiknias could have partly formed at low W/R ratios at high $\left(>300^{\circ} \mathrm{C}\right)$ and low temperatures, but also at relatively low temperatures $\left(\approx 100^{\circ} \mathrm{C}\right)$ at high W/R ratios; (2) serpentinites in the other exposures could only have formed at low temperatures $\left(\approx 50^{\circ} \mathrm{C}\right)$ and high $W / R$ ratios; (3) phyllites similarly could have interacted only at high W/R ratios and temperatures of 100 to $200^{\circ} \mathrm{C}$; (4) gabbros are required to have interacted at relatively low temperatures $\left(<200^{\circ} \mathrm{C}\right)$ and high W/R ratios. Of these interpretations, those regarding the phyllites and nonmassive serpentinites are reasonable, but the possibility regarding the gabbros which show high temperature initial amphibolite facies assemblages is less satisfactory. The discrepancy could be avoided if fluids with $\delta^{18} \mathrm{O}$ values higher than that of ocean water were involved. An examination of Figure 12 shows that an increase in the $\delta^{18} \mathrm{O}$ of the alteration fluid to about $3 \%$ could account for the observed compositional ranges in all rocks. Such an 
${ }^{18} \mathrm{O}$-enriched fluid could be produced by high temperature oceanic alteration as suggested by Gregory \& Taylor (1981).

Finally, it can be noted that the highest $\delta^{18} \mathrm{O}$ values of all rocks are found in sheared rocks from tectonic contacts (Fig. 11). These include phyllonites and amphibolites at the base of the massive serpentinites and sheared talc-tremolite rocks at the base of the phyllite unit at Chiknias. These $\delta^{18} \mathrm{O}$ values are significantly higher than the other Chiknias rocks and indicate that these sheared rocks, the fault planes on which tectonic movement occurred, have undergone extensive interaction with external higher $\delta^{18} \mathrm{O}$ fluids.

\section{Discussion}

Examination of the six exposures of the Upper tectonic Unit on Tinos has shown that they include meta-basalts, meta-gabbros and serpentinites that can be interpreted as parts of a dismembered metamorphosed ophiolite sequence. The geological history of Tinos ophiolitic slices is depicted in the following section and summarized in Table 3 and Figure 13. The petrographic, major and trace element and stable isotope data show that all the rocks underwent an extensive ocean floor alteration history. High temperature alteration during the generation of the ocean crust affected only the gabbros, causing amphibolitization. The high temperature hydrothermal metamorphism did not extend below the gabbros, and did not affect the deeper ultramafic rocks, as has also been observed in intact ophiolites (e.g. Oman: Gregory \& Taylor, 1981). This was explained by the impermeability of deeper parts of the oceanic crust due to closure of open cracks at confining pressures higher than $1 \mathrm{kbar}$ (Boudier \& Nicolas, 1985; Paterson, 1978).

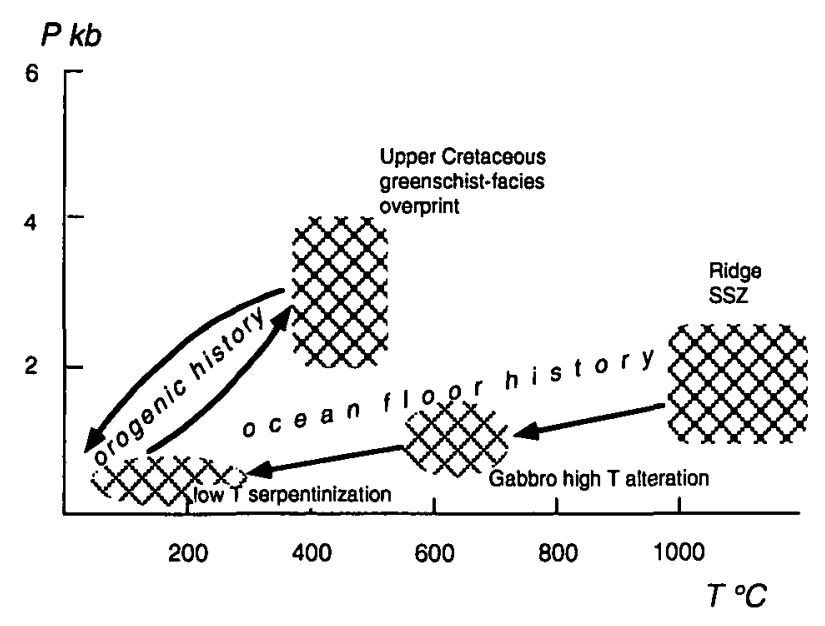

Figure 13. Schematic diagram illustrating the main stages of the pressure $v s$ temperature path of the Tinos ophiolite. High temperature metamorphism of the oceanic crust at the ridge was followed by cooling and low temperature lizardite serpentinization. Subsequent burial in the orogen and heating led to the late Cretaceous greenschist-facies metamorphic phase.
Later on, ultramafic rocks (and probably shallower rocks as well) were also altered in an oceanic setting, but at much lower temperatures, i.e. after they have already cooled. The lizardite serpentinization, which occurred at low temperatures, can be explained as having occurred after the ultramafic rocks have cooled lengthily $(\geq 50 \mathrm{Ma})$ in situ. Yet, due to the poor permeability mentioned above, it is more reasonable to assume that tectonic disturbance has brought the ultramafic rocks into direct contact with sea-water, possibly after a much shorter time. The inferred occurrence of a metamorphic sole, which records detachment and overthrusting of a young $(\leq 10 \mathrm{Ma})$ and still hot oceanic slab, favours tectonism shortly after the ophiolite suite was formed. Tectonism after cooling involved thrusting which caused repetition and inversion of the original order of the oceanic suite. A by-product of the thrusting was the tectono-sedimentary intermingling of melanges and ophicalcites.

Regional metamorphism of all the ophiolite components at greenschist-facies conditions induced crystallization of new mineralogical assemblages (e.g. antigorite + forsterite in serpentinites) and formed a foliation in suitable rocks (phyllites, meta-gabbroic blocks). The regional metamorphic event overprinted, and hence postdated, the early alteration mineralogy, and the formation of the tectono-sedimentary mixtures. The temperatures of $400-500^{\circ} \mathrm{C}$, attained at the peak of the regional metamorphism, necessitate considerable burial $(\geq 10 \mathrm{~km}$ ?) within the orogen. We therefore suggest that the Tinos ophiolite was metamorphosed within a pile of thrust sheets. The piling up of ophiolite nappes, and perhaps also of nappes of other rocks by thrusting, is therefore considered to have created the necessary overburden to cause metamorphism at greenschist-facies conditions.

A normal fault at the base of the Tinos ophiolite, which omitted a thick crustal section beneath it, juxtaposed the ophiolite directly over the rocks of the Blueschist Unit (Lower Unit) in early Miocene time (Avigad \& Garfunkel, 1991). This calls for extensional tectonics. Such a deformation regime can explain the attenuation of Tinos ophiolitic slices.

The Tinos meta-ophiolitic slices, dated at $70 \mathrm{Ma}$, and perhaps associated with a slice including meta-acidites of the same age at Mt Chiknias (D. Avigad, pers. comm.), are probably genetically related to other late Cretaceous low pressure metamorphic rocks in the Aegean region, including some ophiolitic-granitic associations (e.g. Syros, Anafi, Crete). An important question is whether the late Cretaceous Tinos ophiolite and some other Cycladic Upper Unit members were high-level parts of a long ( 25 Ma) accretion-subduction process of which the Eocene blueschist ophiolite remnants are deep-level representatives. In that case late Cretaceous age determinations in the Tinos Upper Unit may represent early stages of accretion, including ophiolite emplacement and intrusion of granites, terminated in the Eocene by collision and high metamorphism metamorphism. Alternatively the Tinos ophiolite might have always been 
Table 3. The geological history of the Upper Unit in Tinos

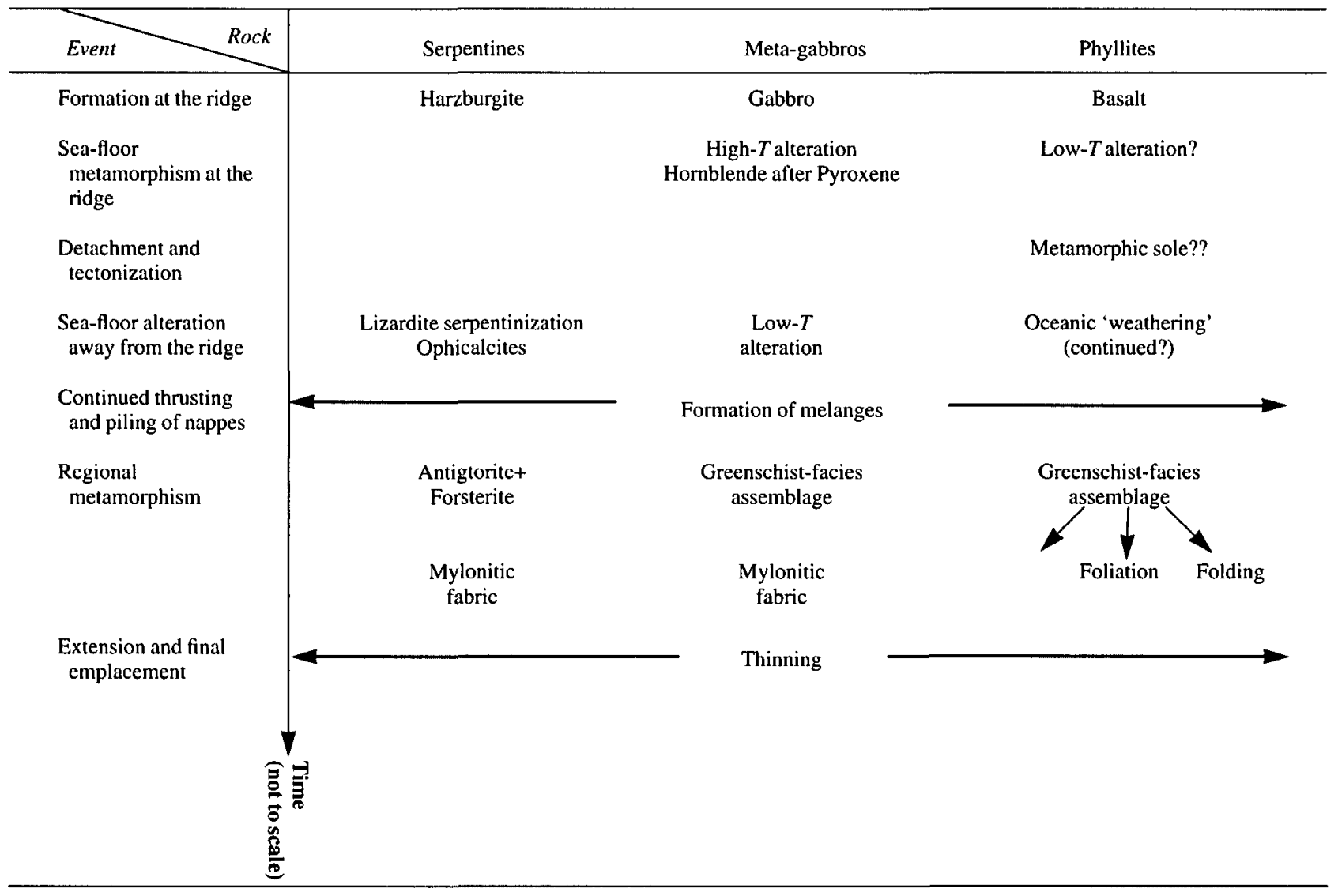

an exotic high-level detached slab which was emplaced quite incidently on top of exhumed blueschists.

Trace element patterns of Tinos mafic phyllites show supra-subduction zone affinities. Similar geochemical features were detected in some of the metabasites of the Blueschist Unit from Tinos (Bröcker, 1991) and adjacent Cycladic islands (M. Schliestedt, unpub. Ph.D. thesis, Technische Universität Braunschweig, 1980; Schliestedt et al. 1994; Seck et al. 1995). However, this can not be taken to prove a common origin because the mafic phyllites of Tinos, like most of the volcanic members of the Eastern Mediterranean Tethyan ophiolitic complexes, show supra-subduction zone affinity (Pearce, Lippard \& Roberts, 1984; Robertson et al. 1991). Moreover, Tinos serpentinites were shown geochemically to have originated from harzburgites and dunites, a feature common to the ultramafic parts of both the Greek ophiolites emplaced in late Jurassic time (Smith, 1993) and to the Peri-Arabian ophiolites from Oman to Troodos and Anatolia emplaced in the late Cretaceous (Boudier \& Nicolas, 1985). Therefore geochemical discrimination is not possible. The palaeogeographical interpretation of the late Cretaceous metamorphic rocks exposed in the Aegean Sea including the Tinos ophiolite must await further research.

Acknowledgements. The research was supported by a grant from the German-Israeli Foundation for Scientific Research and Developement. Permission for field work in Greece was granted by the director of the I.G.M.E. in Athens. We thank T. J. B. Holland for introducing us to the latest version of Thermocalc. Thanks are also due to J. E. Dixon and an unknown reviewer for critical reviews of the manuscript, which significantly contributed to its improvement.

\section{References}

Alt, J. C., Muehlenbachs, K. \& Honnorez, J. 1986. An oxygen isotopic profile through the upper kilometer of the oceanic crust, DSDP Hole 504B. Earth and Planetary Science Letters 80, 217-29.

AltherR, R., Schliestedt, M., OKrusch, M., Seidel, E., Kreuzer, H., Harre, W., Lenz, H., Wendt, I. \& WaGner, G. A. 1979. Geochronology of high pressure rocks on Sifnos (Cyclades, Greece). Contributions to Mineralogy \& Petrology 70, 245-55.

Altherr, R., Kreuzer, H., Wendt, I., Lenz, H., WaGner, G. A., Keller, J., HarRe, W. \& Höhndorf, A. 1982. A Late Oligocene/Early Miocene high temperature belt in the Attic-Cycladic crystalline complex (SE Pelagonian, Greece). Geologisches Jahrbuch E23, 97-164.

Altherr, R., Henjes-Kunst, F., Matthews, A., Friedrichsen, H. \& HANSEN, B. T. 1988. O-Sr isotopic variations in Miocene granitoids from the Aegean: Evidence for an origin by combined assimilation and fractional crystallization. Contributions to Mineralogy \& Petrology 100 , $528-41$.

Aubouin, J., Bonneau, M., Celet, P., Charvet, J., Clement, B., Degardin, J. M., Dercourt, J., Ferriére, J., Fleury, J. J., Guernet, C., Maillot, H., Mania, J., Mansy, J. L., Terry, J., Thiebault, F., Tsoflias, P. \& Verriez, J. J. 
1970. Contribution à la géologie des Hellénides: le Gavrovo, le Pinde et la zone ophiolitique Subpélagonienne. Annales de la Société géologique du Nord 90,277-306.

AviGAD, D. \& GARFUNKEL, Z. 1989. Low-angle faults above and below a blueschist belt - Tinos Island, Cyclades, Greece. Terra Nova 1, 182-7.

AVIGAD, D. \& GaRfUnKel, Z. 1991. Uplift and exhumation of high-pressure metamorphic terrains: The example of the Cycladic blueschist belt (Aegean Sea). Tectonophysics 188, 357-72.

Avigad, D., Matthews, A., Evans, B. W. \& Garfunkel, Z. 1992. Cooling during the exhumation of a blueschist terrane: Sifnos (Cyclades), Greece. European Journal of Mineralogy 4,619-34.

Beccaluva, L., Di Girolamo, P., Macciotta, G. \& Morra, V. 1983. Magma affinities and fractionation trends in ophiolites. Ofioliti 8, 307-24.

Bernoulli, D. \& Weissert, H. 1985. Sedimentary fabrics in Alpine ophicalcites, South Pennine Arosa zone, Switzerland. Geology 13, 755-8.

Biju-Duval, B., Dercourt, J. \& Le Pichon, X. 1977. From the Tethys ocean to the Mediterranean seas: A plate tectonic model of the evolution of the Western Alpine system. In Structural History of the Mediterranean Basins (eds B. Biju-Duval and L. Montadert), pp. 143-64. Paris: Editions Technip.

BonNEAU, M. 1984. Correlation of the Hellenide nappes in the south-east Aegean and their tectonic reconstruction. In The Geological Evolution of the Eastern Mediterranean (eds J. E. Dixon and A. H. F. Robertson), pp. 517-28. Geological Society of London Special Publication no. 17. London, Oxford: Blackwell Scientific Publications.

Boudier, F. \& Coleman, R. G. 1981, Cross section through the peridotite in the Samail ophiolite, southeastern Oman mountains. Journal of Geophysical Research $\mathbf{8 6 B}$, 2573-92.

Boudier, F., Ceuleneer, G. \& Nicolas, A. 1988. Shear zones, thrusts and related magmatism in the Oman ophiolite: Initiation of thrusting on an oceanic ridge. Tectonophysics 151, 275-96.

BOUDIER, F. \& NiCOLAS, A. 1985. Harzburgite and lherzolite subtypes in ophiolitic and oceanic environments. Earth and Planetary Science Letters 76, 84-92.

BRÖCKER, M. 1990a. Blueschist-to-greenschist transition in metabasites from Tinos Island, Cyclades, Greece: Compositional control or fluid infiltration? Lithos 25 , 25-39.

BRÖCKER, M. 1990b. Die metamorphe vulcanosedimentäre abfolge der Insel Tinos (Kykladen, Griechenland) - geologie, petrographie und mineralchemie einer grunschiefer faziell uberpragten hochdruck-/niedrigtemperatur-abfolge. Geotektonische Forschungen 74, 1-107.

BRÖCKER, M. 1991. Geochemistry of metabasic HP/LT rocks and their greenschist facies and contact metamorphic equivalents, Tinos Island (Cyclades, Greece). Chemie der Erde 51, 155-71.

Bröcker, M., Kreuzer, A., Matthews, A. \& OKrusch, M. 1993. ${ }^{40} \mathrm{Ar} /{ }^{39} \mathrm{Ar}$ and oxygen isotope studies of poly-metamorphism from Tinos Island, Cycladic blueschist belt, Greece. Journal of Metamorphic Geology 11, 223-40.

Buick, I. S. 1991. The late Alpine evolution of an extensional shear zone, Naxos, Greece. Journal of the Geological Sociery, London 148, 93-103.

BurkhaRd, D. J. M. \& O'Neil, J. R. 1988. Contrasting serpentinization processes in the eastern Central Alps. Contributions to Mineralogy \& Petrology 99,498-506.
Clayton, R. N. \& Mayeda, T. K. 1963. The use of bromine pentafluoride in the extraction of oxygen from oxides and silicates for isotopic analyses. Geochimica et Cosmochimica Acta 53, 725-34.

Dewey, J. F., Pitman, W. C. III, Ryan, W. B. F. \& Bonin, J. 1973. Plate tectonics and the evolution of the Alpine system. Bulletin of the Geological Society of America 84, $3137-80$.

DiXON, J. E. \& RidLEY, J. 1987. Syros. In Chemical Transport in Metasomatic Processes (ed. H. C. Helgeson), pp. 489-501. NATO ASI series. Reidel Publishing Company.

Dürr, S., Altherr, R., Keller, J., OKrusch, M. \& Seidel, E. 1978a. The median Aegean crystalline belt: Stratigraphy, structure, metamorphism, magmatism. In Alps, Appenines, Hellenides (eds H. Cloos, D. Roeder and K. Schmidt ), pp. 455-77. IUGS Report no. 38. Stuttgart: Schweizerbart.

Dürr, S., Seidel, E., Kreuzer, H. \& Harre, W. $1978 b$. Témoins d'un métamorphisme d'âge crétacé supérieur dans l'Égéide: datations radiométriques de minéraux provenant de l'île de Nikouriá (Cyclades, Grèce). Bulletin de la Société Géologique de France 2, 209-13.

Evans, B. W. 1977. Metamorphism of Alpine peridotite and serpentinite. Annual Reviews in Earth and Planetary Science $5,397-447$.

GaUtier, P. \& Brun, J.P. 1994. Crustal-scale geometry and kinematics of late-orogenic extension in the central Aegean (Cyclades and Evvia Island). Tectonophysics 238, $399-424$.

Girardeau, J., Marcoux, J. \& Zao Yougong, 1984. Lithologic and tectonic environment of the Xigaze ophiolite (Yarlung Zangbo suture zone, Southern Tibet, China) and kinematics of its emplacement. Eclogae Geologicae Helvetiae 77, 153-70.

GREGORY, R. T. \& TAYLOR, H. P., JR. 1981. An oxygen isotope profile in a section of Cretaceous oceanic. crust, Samail ophiolite, Oman: Evidence for $18 \mathrm{O}$ buffering of the oceans by deep $(>5 \mathrm{~km})$ seawater-hydrothermal circulation at mid-ocean ridges. Journal of Geophysical Research 86B, 2737-55.

Holland, T. J. B. \& Powell, R. 1990. An enlarged and updated internally consistent thermodynamic dataset with uncertainties and correlations: the system $\mathrm{K}_{2} \mathrm{O}-\mathrm{Na}_{2} \mathrm{O}-\mathrm{CaO}-\mathrm{MnO}-\mathrm{FeO}-\mathrm{Fe}_{2} \mathrm{O}_{3}-\mathrm{Al}_{2} \mathrm{O}_{3}-\mathrm{TiO}_{2}-\mathrm{SiO}_{2}-$ $\mathrm{C}-\mathrm{H}_{2}-\mathrm{O}_{2}$. Journal of Metamorphic Geology 8, 89-124.

ITO, E. \& ANDERSON, A. T., JR. 1983. Submarine metamorphism of gabbros from the Mid-Cayman Rise: Petrographic and mineralogic constraints on hydrothermal processes at slow-spreading ridges. Contributions to Mineralogy \& Petrology 82, 371-88.

Jagoutz, E., Palme, H., Baddenhausen, H., Blum, K., Cendales, M., Dreibus, G., Spettel, E., Lorenz, V. \& WÄNKE, H. 1979. The abundances of major, minor and trace elements in the earth's mantle as derived from primitive ultramafic nodules. In Early Solar System and Lunar Regolith (eds R. B. Merril, D. D. Bogard, F. Hoerz, D. S. McKay and P. C. Robertson), pp. 2031-50. Proceedings of the 10th Conference on Lunar and Planetary Sciences, Vol. 2.

Jones, G. \& RoBERTSON, A. H. F. 1991. Tectono-stratigraphy and evolution of the Mesozoic Pindos ophiolite and related units, northwestern Greece. Journal of the Geological Society, London 148, 267-88.

KYSER, T. K., O'NeIL, J.R. \& CARMICHAEL, I. S.E. 1982. Genetic relations among basic lavas and ultramafic nodules: Evidence from oxygen isotope compositions. Contributions to Mineralogy \& Petrology 81, 88-102. 
Le BAS, M. J., Le MAitre, R. W., Streckeisen, A. \& ZANETtin, B.A. 1986. Chemical classification of volcanic rocks based on the total alkali-silica diagram. Journal of Petrology 27, 745-50.

LEAKE, B. E. 1978. Nomenclature of amphiboles. American Mineralogist 63, 1023-52.

LEE, J. \& LISTER, G. S. 1992. Late Miocene ductile extension and detachment faulting, Mykonos, Greece. Geology 20 , $121-4$.

Lister, G. S., Banga, G. \& Feenstra, A. 1984. Metamorphic core complexes of Cordilleran type in the Cyclades, Aegean Sea, Greece. Geology 12, 221-5.

Maluski, H., Bonneau, M. \& Kienast, J. R. 1987. Dating metamorphic events in the Cycladic area: ${ }^{39} \mathrm{Ar} /{ }^{40} \mathrm{Ar}$ data from metamorphic rocks of the island of Syros (Greece). Bulletin de la Société Géologique de France 8, 833-42.

MatTEY, D. P., MARSH, M. G. \& TARNEY, J. 1980. The geochemistry, mineralogy and petrology of basalts from the West Philippine and Parece Vela basins and from the PalauKyushu and West Mariana ridges, Deep Sea Drilling Project Leg 59. In Initial Reports of the Deep Sea Drilling Project 59 (eds L. Kroenke, R. Scott et al.), pp. 753-800. Washington, D.C.: U.S. Government Printing Office.

MatTHEWS, A. 1994. Oxygen isotope geothermometers for metamorphic rocks. Journal of Metamorphic Geology 12, 211-19.

Matthews, A. \& Schliestedt, M. 1984. Evolution of the blueschist and greenschist facies rocks of Sifnos, Cyclades, Greece. Contributions to Mineralogy \& Petrology 88, 150-63.

MCCREA, J. M. 1950. On the isotopic chemistry of carbonates and a paleotemperature scale. Journal of Chemical Physics $18,849-57$.

MeLidonis, N.G. 1980. The geological structure and mineral deposits of Tinos island (Cyclades, Greece). The Geology of Greece 13, 1-80. Athens: IGME.

MOORES, E. J. 1969. Petrology and structure of the Vourinos ophiolitic complex of Northern Greece. Geological Society of America Special Paper no. 118.

MuEHLENBACHS, K. 1986. Alteration of the oceanic crust and the ${ }^{18} \mathrm{O}$ history of seawater. In Stable Isotopes in High Temperature Geological Processes (eds J. W. Valley, H. P. Taylor, Jr and J. R. O'Neil), pp. 425-44. Mineralogical Society of America Reviews in Mineralogy Series, Vol. 16.

Mullen, E. D. 1983 . $\mathrm{MnO} / \mathrm{TiO}_{2} / \mathrm{P}_{2} \mathrm{O}_{5}$ : a minor element discriminant for basaltic rocks of oceanic environments and its implications for petrogenesis. Earth and Planetary Science Letters 62, 53-62.

Nicolas, A. 1989. Structures of Ophiolites and Dynamics of Oceanic Lithosphere. Dordrecht: Kluwer Academic Publishers, 367 pp.

O'NeIL, J. R. \& TAYLOR, H. P., JR. 1967. The oxygen isotope and cation exchange chemistry of feldspars. American Mineralogist 52, 1414-37.

OTtONELlO, G., ERNST, W. G. \& JoRON, J. L. 1984. Rare earth and $3 \mathrm{~d}$ transition element geochemistry of peridotitic rocks: I. Peridotites from the western Alps. Journal of Petrology 25, 343-72.

PaPANIKOLAOU, D. J. 1980. Contribution to the geology of the Aegean Sea: The island of Paros. Annales Géologiques des Pays Helléniques 30/1, 65-95.

Papanikolaou, D. 1987. Tectonic evolution of the Cycladic blueschist belt (Aegean Sea, Greece). In Chemical Transport in Metasomatic Processes (ed. H. C. Helgeson), pp. 429-50. NATO ASI series. Reidel Publishing Company.
PATERSON, M. S. 1978. Experimental Rock Deformation - The Brittle field. Berlin, Heidelberg, New York: SpringerVerlag, $254 \mathrm{pp}$.

Patzak, M., OKrusch, M. \& Kreuzer. H. 1994. The Akrotiri Unit on the island of Tinos, Cyclades, Greece: Witness to a lost terrane of Late Cretaceous age. Neues Jahrbuch für Geologie und Paläontologie Abhandlungen 194 211-52.

PeARCE, J. A. 1983. Role of sub-continental lithosphere in magma genesis at active continental margins. In Continental Basalts and Mantle Xenoliths (eds C. J. Hawkesworth and M. J. Norry), pp. 230-49. Nantwich: Shiva Publishing.

Pearce, J. A. \& CANN, J. R. 1973. Tectonic setting of basic volcanic rocks determined using trace element analyses. Earth and Planetary Science Letters 19, 290-300.

Pearce, J. A., Lippard, S.J. \& RoberTs, S. 1984. Characteristics and tectonic significance of supra-subduction zone ophiolites. In Marginal Basin Geology (eds B. P. Kokelaar and M. F. Howells), pp. 77-94. Geological Society of London Special Publication no. 16. London, Oxford: Blackwell Scientific Publications.

Powell, R. \& Holland, T. J. B. 1988. An internally consistent dataset with uncertainties and correlations. 3. Applications to geobarometry worked examples and a computer program. Journal of Metamorphic Geology 6, 173-204.

Reinecke, T., Altherr, R., Hartung, B., Hatzipanagiotou, K., Kreuzer, H., Harre, W., Klein, H., Keller, J., GEENEN, E. \& BÖGER, H. 1982. Remnants of a Late Cretaceous high temperature belt on the Island of Anafi (Cyclades, Greece). Neues Jahrbuch für Mineralogie Abhandlungen 145, 157-82.

RIDLEY, J. 1984. Listric normal faulting and reconstruction of the synmetamorphic structural pile of the Cyclades. In The Geological Evolution of the Eastern Mediterranean (eds J. E. Dixon and A. H. F. Robertson), pp. 755-62. Geological Society of London Special Publication no. 17. London, Oxford: Blackwell Scientific Publications.

Robertson, A. H. F., Clift, P. D., Degnan, P. J. \& Jones, G. 1991. Palaeogeographic and palaeotectonic evolution of the Eastern Mediterranean Neotethys. Palaeogeography, Palaeoclimatology, Palaeoecology 87, 289-343.

Robinson, P., Schumacher, J.C. \& Spear, F. S. 1982. Formulation of electron probe analyses. In Amphiboles: Petrology and Experimental Phase Relations (eds D. R. Veblen and P. H. Ribbe), pp. 6-9. American Mineralogical Society Reviews in Mineralogy Series, Vol.9B.

SAUnders, A. D. \& TARNEY, J. 1979. The geochemistry of basalts from a back-arc spreading centre in the Scotia Sea. Geochimica et Cosmochimica Acta 43, 555-72.

SAUNDERS, A. D. \& TARNEY, J. 1984. Geochemical characteristics of basaltic volcanism within back-arc basins. In Marginal Basin Geology (eds B. P. Kokelaar and M. F. Howells), pp. 59-76. Geological Society of London Special Publication no. 16. London, Oxford: Blackwell Scientific Publications.

SCHLIESTEDT, M. 1986. Eclogite-blueschist relationships as evidenced by mineral equilibria in the high-pressure rocks of Sifnos (Cycladic islands), Greece. Journal of Petrology 27, 1437-59.

Schliestedt, M., AltherR, R. \& Matthews, A. 1987. Evolution of the Cycladic crystalline complex: Petrology, isotope geochemistry and geochronology. In Chemical Transport in Metasomatic Processes (ed. H. C. Helgeson), pp. 389-428. NATO ASI series. Reidel Publishing Company. 
Schliestedt, M., Bartsch, V., Carl, M., Matthews, A. \& Henjes-Kunst, F. 1994. The $P-T$ path of greenschistfacies rocks from the island of Kithnos (Cyclades, Greece). Chemie der Erde 54, 281-96.

SCHLJeSTEDT, M. \& MATTHEws, A. 1987. Transformation of blueschist to greenschist facies rocks as a consequence of fluid infiltration, Sifnos (Cyclades), Greece. Contributions to Mineralogy \& Petrology 97, 237-50.

Seck, H. A., Koetz, J., OKrusch, M., Seidel, E. \& Stosch, H. G. 1995. Geochemistry of a meta-ophiolite suite: The association of meta-gabbros, eclogites and glaucophanites on the Island of Syros, Greece. European Journal of Mineralogy, in press.

Seidel, E., Okrusch, M., Kreuzer, H., RaschKa, H. \& Harre, W. 1981. Eo-alpine metamorphism in the uppermost unit of the Cretan nappe system - petrology and geochemistry. Part 2. Synopsis of radiometric dates from high temperature metamorphics and associated ophiolites. Contributions to Mineralogy \& Petrology 76, 351-61.

SMITH, A. G. 1993. Tectonic significance of the Hellenic-Dinaric ophiolites. In Magmatic Processes and Plate Tectonics (eds H. M. Prichard, T. Alabaster, N. B. W. Harris and C. R. Neary), pp. 213-43. Geological Society of London Special Publication no. 76. London, Oxford: Blackwell Scientific Publications.

Smith, A. G., Hynes, A. J., Menzies, M., Nisbet, E. G., Price, I., Welland, M. J. \& FerriÉRe, J. 1975. The stratigraphy of the Othris mountains, Eastern Central Greece: a deformed Mesozoic continental margin sequence. Eclogae Geologicae Helvetiae 68, 463-81.

Smith, A. G., WoodCock, N. H. \& NAYloR, M. A. 1979. The structural evolution of a Mesozoic continental margin, Othris mountains, Greece. Journal of the Geological Society, London 136, 589-603.

SPEAR, F. S. 1981. An experimental study of hornblende stability and compositional variability in amphibolite. American Journal of Science 281, 697-734.

STAKES, D. S. \& O'NeIL, J. R. 1982. Mineralogy and stable isotope geochemistry of hydrothermally altered oceanic rocks. Earth and Planetary Science Letters 57, 285-304.
TAYLOR, H. P., JR. 1968. The oxygen isotope geochemistry of igneous rocks. Contributions to Mineralogy \& Petrology 19, $1-71$.

TAYLOR, H. P., JR. 1977. Water/rock interactions and the origin of $\mathrm{H}_{2} \mathrm{O}$ in granitic batholiths. Journal of the Geological Society, London 133, 509-58.

TrommsdorfF, V. \& Evans, B. W. 1974. Alpine metamorphism of peridotitic rocks. Schweizerische Mineralogische und Petrographische Mitteilungen 54, 333-52.

VALLANCE, T. G. 1974. Spilitic degradation of a tholeiitic basalt. Journal of Petrology 15, 79-96.

VANCE, J. A. \& DUNGAN, M. A. 1977. Formation of peridotites by deserpentinization in the Darrington and Sultan areas, Cascade Mountains, Washington. Geological Society of America Bulletin 88, 1497-1508.

WACHTER, E. A. \& HAYES, J. M. 1985. Exchange of oxygen isotopes in carbon dioxide- phosphoric acid systems. Chemical Geology 52, 365-74.

WenNER, D. B. \& TAYLOR, H. P., JR. 1973. Oxygen and hydrogen isotope studies of the serpentinization of ultramafic rocks in oceanic environments and continental ophiolite complexes. American Journal of Science 273, 207-39.

WHITTAKER, E. J. W. \& ZUSSMAN, J. 1956. The characterization of serpentine minerals by X-ray diffraction. Mineralogical Magazine 31, 107-26.

WiCKs, F. J. \& WhITTAKER, E. J. W. 1977. Serpentine textures and serpentinization. Canadian Mineralogist 15, 459-88.

Will, T. M., Powell, R. \& Holland, T. J. B. 1990. A calculated petrogenic grid for ultramafic rocks in the system Cao-FeO-MgO- $\mathrm{Al}_{2} \mathrm{O}_{3}-\mathrm{SiO}_{2}-\mathrm{CO}_{2}-\mathrm{H}_{2} \mathrm{O}$ at low pressures. Contributions to Mineralogy \& Petrology 105 , $347-58$.

Wood, D. A., MatTey, D. P., Joron, J. L., Marsh, N. G., TARNEY, J. \& TREUIL, M. 1980. A geochemical study of 17 selected samples from basement cores recovered at Sites 447, 448, 449, 450 and 451, Deep Sea Drilling Project Leg 59. In Initial Reports of the Deep Sea Drilling Project 59 (eds L. Kroenke, R. Scott et al.), pp. 743-52. Washington, D.C.: U.S. Government Printing Office. 